I NTER NATIONAL MONETARY FUND
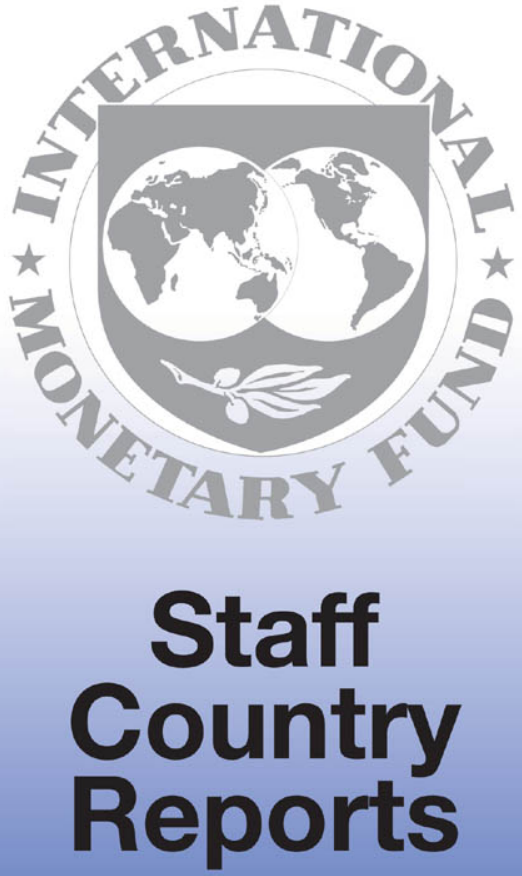


\section{Luxembourg: 2011 Article IV Consultation-Staff Report; Informational Annex; Public Information Notice on the Executive Board Discussion; and Statement by the Executive Director for Luxembourg}

Under Article IV of the IMF's Articles of Agreement, the IMF holds bilateral discussions with members, usually every year. In the context of the 2011 Article IV consultation with Luxembourg, the following documents have been released and are included in this package:

- $\quad$ The staff report for the 2011 Article IV consultation, prepared by a staff team of the IMF, following discussions that ended on April 4, 2011 with the officials of Luxembourg on economic developments and policies. Based on information available at the time of these discussions, the staff report was completed on April 27, 2011. The views expressed in the staff report are those of the staff team and do not necessarily reflect the views of the Executive Board of the IMF.

- $\quad$ A Public Information Notice (PIN) summarizing the views of the Executive Board as expressed during its May 13, 2011 discussion of the staff report that concluded the Article IV consultation.

- $\quad$ A statement by the Executive Director for Luxembourg.

The policy of publication of staff reports and other documents allows for the deletion of market-sensitive information.

Copies of this report are available to the public from

International Monetary Fund $\bullet$ Publication Services

$70019^{\text {th }}$ Street, N.W. • Washington, D.C. 20431

Telephone: (202) 623-7430 • Telefax: (202) 623-7201

E-mail: publications@imf.org Internet: http://www.imf.org

\section{International Monetary Fund Washington, D.C.}


INTERNATIONAL MONETARY FUND

LUXEMBOURG

Staff Report for the 2011 Article IV Consultation

Prepared by the Staff Representatives for the 2011 Consultation with Luxembourg

Approved by Ajai Chopra and Jan Kees Martijn

April 27, 2011

Executive Summary

Growth prospects: Growth is projected to slow to $3 \frac{1 / 4}{4}$ percent in 2011, reflecting prospects in core Europe, ongoing bank restructuring, and the withdrawal of fiscal support. Economic activity could be stronger if global financial markets avoid severe turbulence and growth in core Europe proves robust. But downside risks prevail. These risks are associated with ongoing concerns regarding sovereign debt in the EU periphery, feedback interactions with the banking sector, and knock on effects on economic activity in core Europe.

Limiting financial sector vulnerabilities: The financial sector has stabilized but banks remain exposed to liquidity and counterparty risks stemming from large exposures to their parent banking groups. Bank exposures to sovereign risk from the EU periphery are also significant, including indirectly through their parent banks. To improve the financial stability policy framework, the FSAP recommended further enhancing on-site supervision and increasing the supervisor's operational independence. There is also a need to strengthen Luxembourg's financial safety net by improving the institutional setup and enhancing the bank resolution toolkit. Still, a number of critical financial policy areas fall beyond the purview of the Luxembourg authorities. They are thus urged to maintain an active involvement in relevant supervisory colleges and continue to pursue pragmatic steps facilitating international collaboration in the area of burden-sharing arrangements for the resolution of cross-border banks.

Achieving sustainable fiscal consolidation: The 2011 budget appropriately begins fiscal consolidation, but the bulk of the adjustment stems from a cap on public investment. In the medium term, this cap should be replaced with current spending cuts - notably by rationalizing social transfers and subsidiesto bolster growth prospects. Fiscal consolidation can be also supported by a full-fledged medium-term budgetary framework with binding multi-year expenditure ceilings. Regardless, should growth slow more than expected, automatic stabilizers should be allowed to operate up to the Maastricht limit.

Reforming the pension system: Parametric reforms are needed to gradually increase the effective and statutory retirement ages to reflect life expectancy gains and align contributions and benefits. The authorities are also urged to expeditiously implement recently approved health care reforms. Putting in place reforms early will facilitate phasing-in adjustments, and establishing periodic automatic reviews of the social security's financial viability would enable timely adjustments.

Boosting competitiveness: Besides continued attention to infrastructure and education, revamping the system of social transfers and subsidies will be needed also to limit adverse work incentives and support investment in human capital. In addition, even though eliminating wage indexation remains advisable in the medium term, excluding food and fuel prices from the reference index would improve the alignment of real wages and labor productivity. Continued efforts are also a need in the short run to curb automatic wage increases to safeguard competitiveness. 


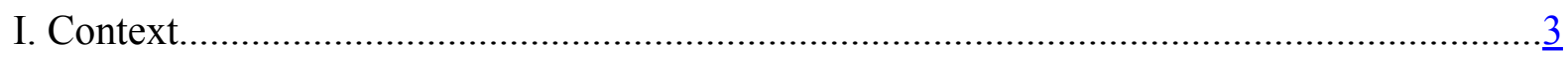

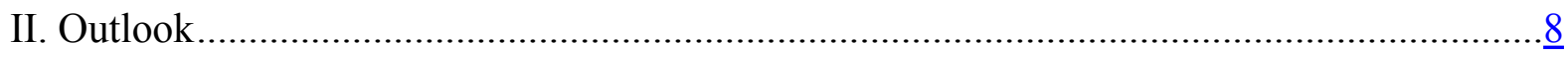

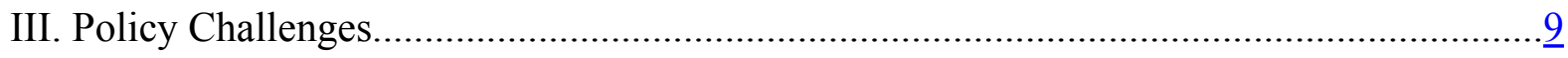

A. Safeguarding Financial Stability …………......................................................

B. Fiscal Consolidation and Pension Reform …………........................................12

C. Long-Run Challenges to Financial-Sector Led Growth and Competitiveness ........15

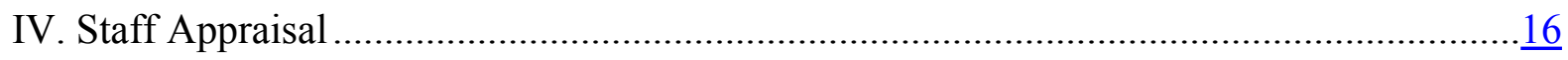

Tables

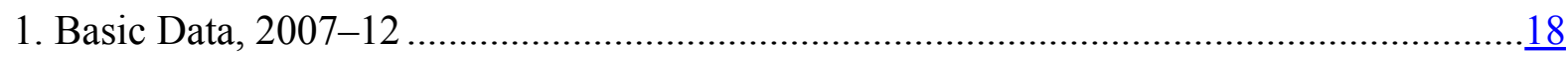

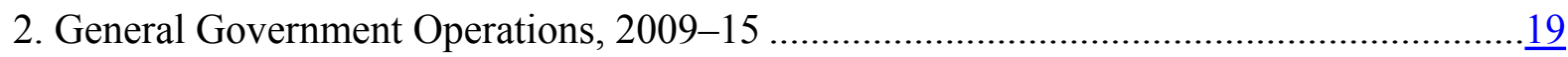

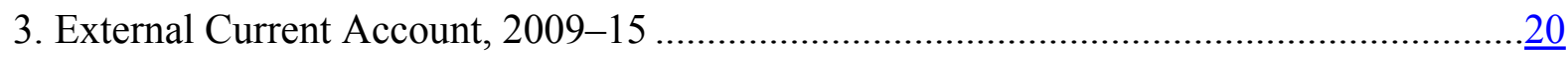

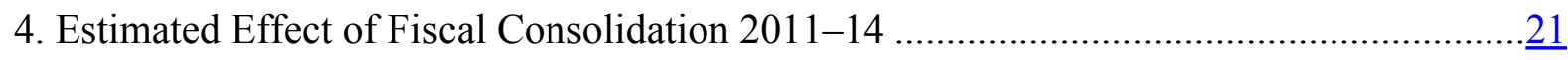

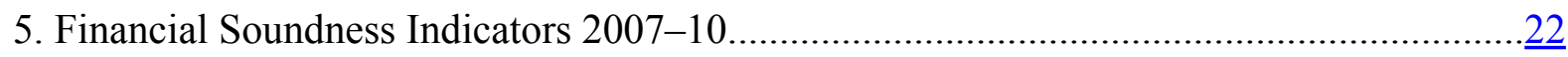

Figures

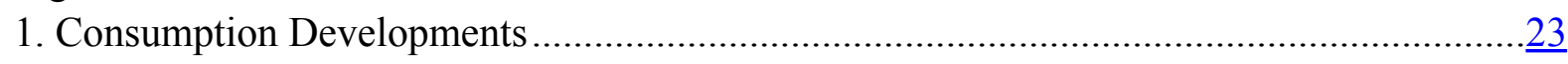

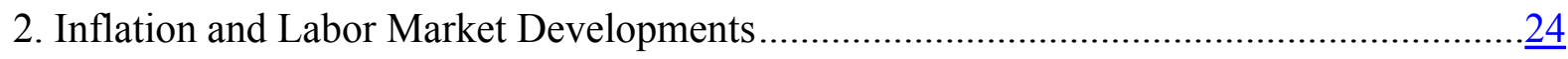

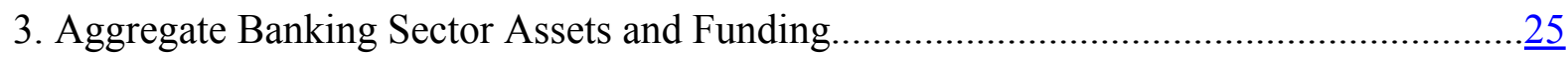

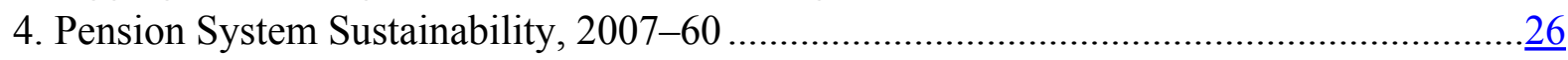

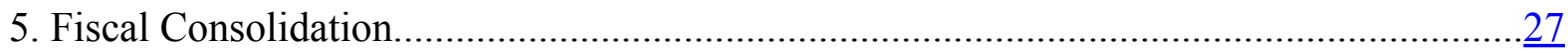

Boxes

1. Recent Developments in Luxembourg's Investment Fund Industry .................................... $\underline{6}$

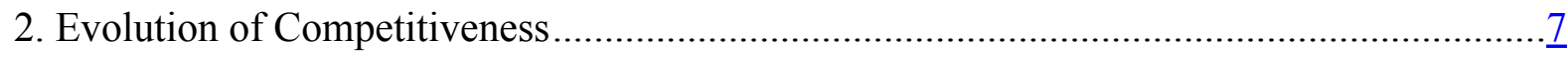

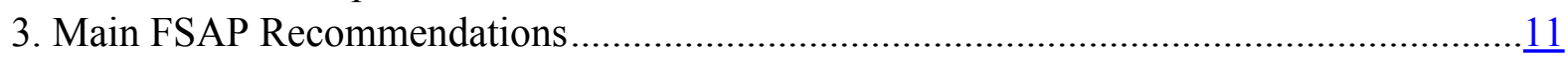

Annex

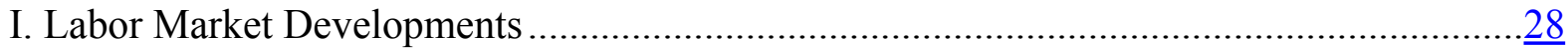

II. The Authorities' Supervisory Response to the Global Financial Crisis..............................29

III: Understanding Luxembourg's Competitiveness and Its Impact on Exports ........................ 


\section{CONTEXT $^{1}$}

\section{Luxembourg's large internationally-interconnected financial sector dominates}

\section{its economy and plays a central role in $\mathbf{E U}$}

financial markets. In the past 20 years, the financial sector-with assets exceeding 70 times GDP — has been the key driver of Luxembourg's economic activity. ${ }^{2}$ The investment fund industry and the banking sector - the financial sector's two main pillars - have been primarily outward oriented but have made substantial contributions to Luxembourg's value added, tax revenues, and employment as well as helped sustain high value-added activities in legal, accounting, and other related services. In addition, the financial sector generates employment for crossborder commuters accounting for a large share of Luxembourg's labor force. ${ }^{3}$ More broadly, Luxembourg's financial sector represents a significant portion of private banking activities, investment fund domiciliation, and primary bond listing in the EU.

\section{An externally-driven economic recovery has continued gathering strength in 2010 .}

Following a smaller-than-expected contraction in 2009 - two-thirds of which associated with the financial sector-a sharp recovery has ensued mirroring developments in core Europe. Early in 2010, activity was supported by restocking, which has ended, and investment. Exports have increased strongly since the third quarter as financial services,

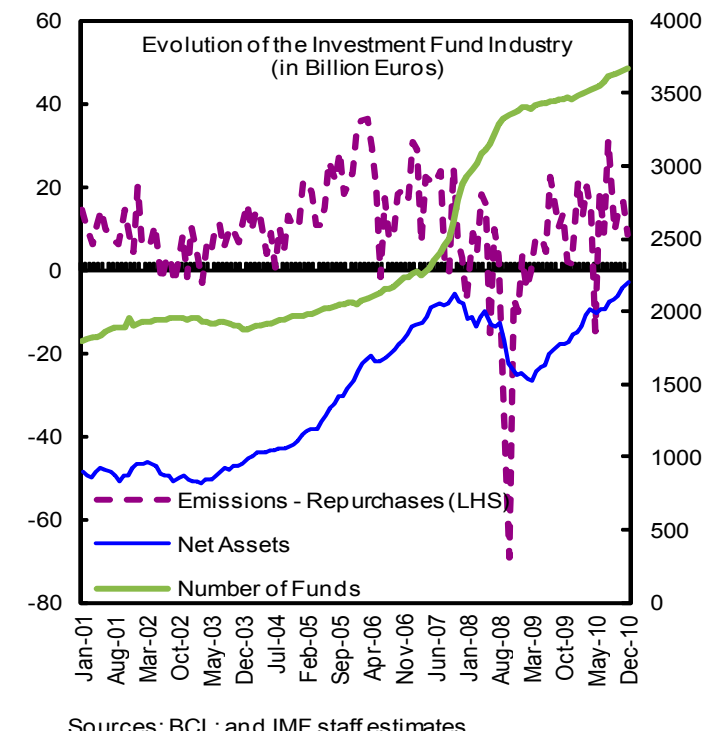

Sources: BCL; and IMF staff estimates.

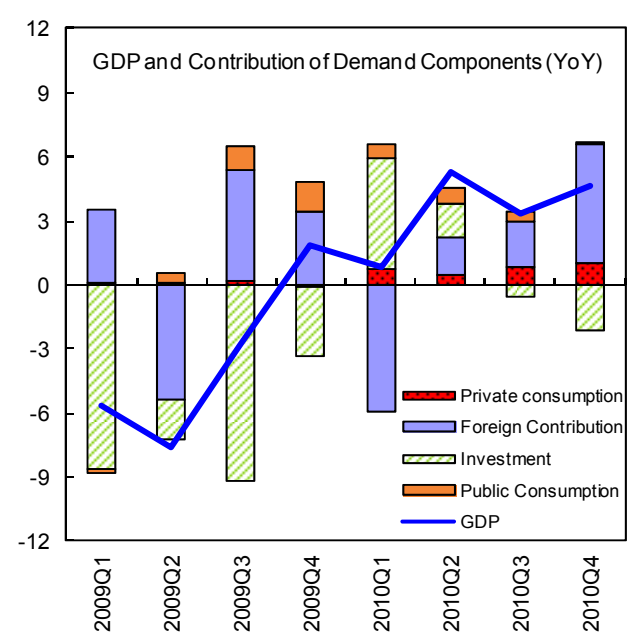

Sources: WEO; and IMF staff calculation

\footnotetext{
${ }^{1}$ A mission team comprising Messrs. Hoffmaister (head) and Vazquez, and Ms. Zhang (all EUR), visited Luxembourg between March 24 and April 4 2011; Mr. Blancher (MCM) joined the mission on March 30. Mr. Mevis (OED) attended the meetings and Mr. Prader (OED) joined the concluding meeting. Luxembourg is an Article VIII country (Informational Annex, Appendix I). Data provision is adequate for surveillance (Informational Annex, Appendix II).

${ }^{2}$ The development of the financial system was initially spurred by an early implementation of the EU passport for investment funds, a low tax environment, and a flexible and responsive regulatory framework.

${ }^{3}$ The share of cross-border workers in Luxembourg's labor force has increased and now stands at about 40 percent.
} 
primarily associated with the investment fund industry, and exports of metal products boomed. The latter have accounted for a strong rebound in industrial activity. Despite a weak labor market, private consumption has gradually improved in line with consumer confidence (Figure 1).
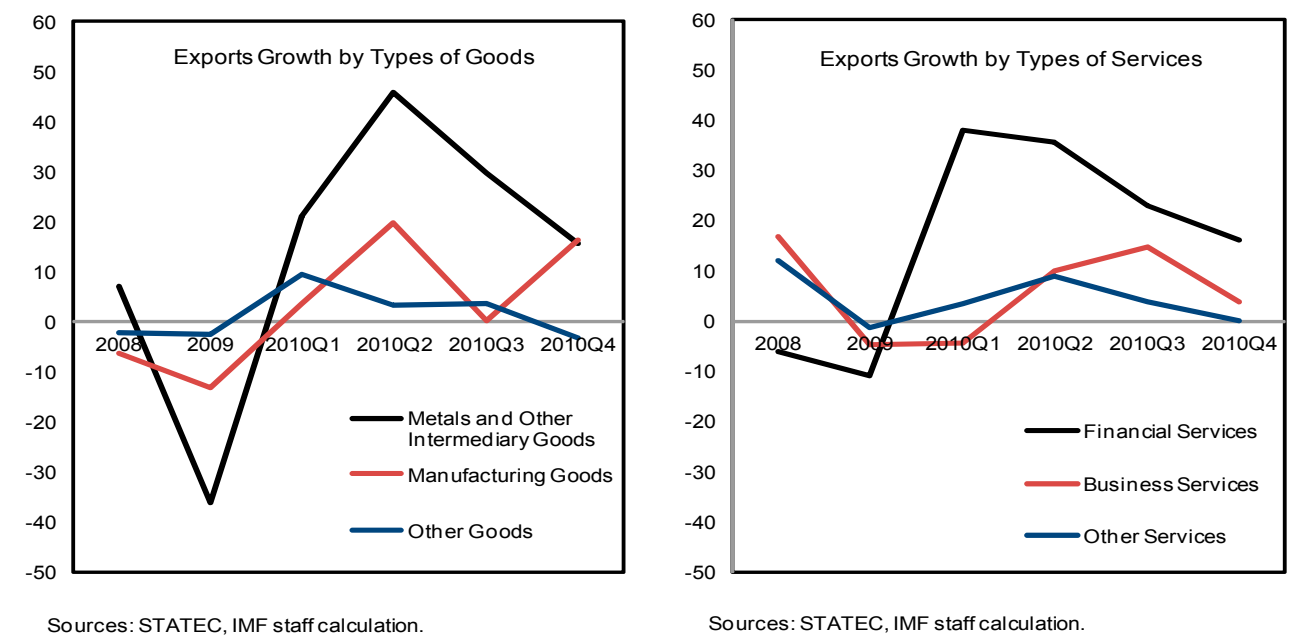

3. The financial sector has stabilized in 2010. No further financial institution has failed, and restructuring has continued, including in the context of EU-approved reorganization plans. Reflecting ongoing deleveraging, bank balance sheets have contracted by $2 \frac{1}{2}$ times GDP in 2010 and declined further in early 2011. In aggregate, bank capitalization has increased and appeared broadly adequate but remained uneven across banks. Interest margins have remained compressed, but bank profits have increased due to strong commission and fee income and lower provisioning needs. In turn, the investment fund industry has experienced a fast recovery, with total assets surpassing their pre-crisis peak (Box 1). Meanwhile, credit conditions in Luxembourg have remained stable with moderate increases in consumer lending spreads, but no widespread tightening in lending standards.

4. Price pressures, while still moderate, have picked up. Headline inflation has increased in the second half of 2010 reflecting global food and fuel price developments and adjustments in some administered prices. Core inflation has trended up more moderately in the face of a sluggish labor market, averaging about 1 1/2 percent in 2010 and a bit higher in early 2011 (Figure 2). Employment growth has gained pace, particularly for temporary workers. Still, the unemployment rate has stabilized at about 6 percent (Annex I). Moreover, official unemployment statistics do not reflect workers participating in employment support schemes - about 2 percent of the labor force - nor do they include cross-border job losses, 
which represent the most variable part of the labor market. ${ }^{4}$ Labor costs have remained subdued despite some increases in layoff compensation, particularly in the banking sector. Average wages have grown well below their historic pace in 2010, but picked up more recently. The latter has resulted from the automatic backward-looking wage indexation adjustment in mid-2010 - Luxembourg is one of the few EU countries with such an indexation — and an increase in minimum wages in early 2011.

5. Fiscal policy has continued to support the economy in 2010. Following substantial fiscal support in the aftermath of the global financial crisis, the fiscal deficit widened from 1 percent of GDP in 2009 to about 13/4 percent of GDP in 2010. In part, this was driven by public investment and enhanced labor market support measures, including an expanded list of eligible sectors and temporary measures to reduce effective labor costs. Still, the fiscal deficit was about 2 percent of GDP lower than budgeted due to higher-than-expected revenues. Strong direct tax collections were partly due to lags in the calculation of taxesreflecting buoyant pre-crisis profits - combined with the authorities' efforts to clear corporate tax arrears as well as increases in subscription tax revenues from investment funds. Indirect taxes also surprised on the upside, primary VAT revenues that more than offset weaker-thanexpected taxes on international transactions.

\section{Led by financial service exports, the current account surplus increased in 2010.}

Export growth has outpaced the euro area while deficits in income and trade accounts widened. In large part, this has reflected the fact that Luxembourg's exports are dominated by services - notably financial services - which together with metal products and intermediate capital goods have experienced strong demand, particularly from Germany and, to a lesser extent, Asia. Reflecting the investment fund industry developments, portfolio investment flows surged in 2010 despite a slowdown in the third quarter. Although competitiveness has improved modestly in 2010-partly due to unwinding of crisis-related labor hoarding — Luxembourg has lost competitiveness over the past decade (Box 2).

\footnotetext{
${ }^{4}$ Unemployed cross-border workers register in their home countries and are not entitled to full payments from Luxembourg's unemployment insurance scheme. Instead, Luxembourg contributes with three months of unemployment benefits to the country of origin computed according to the benefits in that country. They do, nonetheless, qualify for other specific labor market programs and related assistance.
} 


\section{Box 1. Recent Developments in Luxembourg's Investment Fund Industry}

Luxembourg's investment fund industry has rebounded vigorously following the peak of the global financial crisis. Having declined by almost 20 percent in 2008, the total value of investment funds' assets increased by an accumulated 44 percent in 2010-11 and posted uninterrupted net inflows in the last seven quarters. As a result, the total value of assets under management has surpassed the $€ 2$ trillion mark attained before the crisis, helping consolidate Luxembourg investment fund industry's leadership in the EU in terms of fund domiciliation. This reflected strong investor demand, migration of funds from other jurisdictions, and valuation changesthe latter accounting for about $2 / 3$ of the

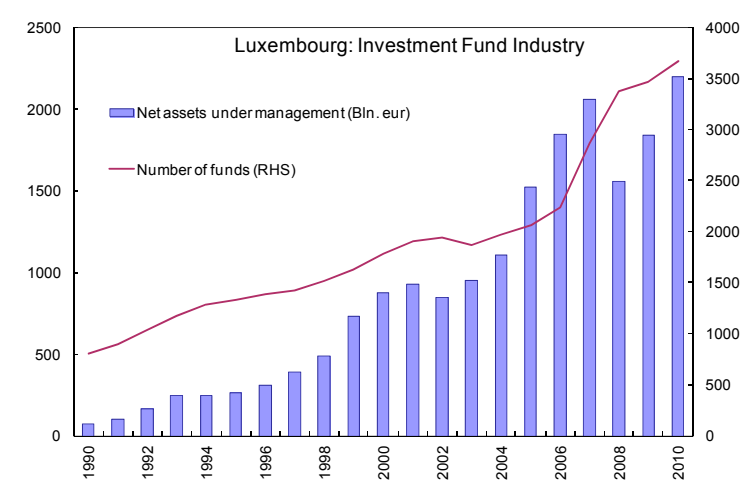
cumulative increase in assets. The bulk of Luxembourg's investment funds are distributed in Europe through an extensive use of the UCITS European brand. Moreover, following years of active promotion in other regions, there is a strong association between Luxembourg's investment fund industry and the UCITS brand, particularly in Asia.

Linkages between investment funds and their sponsoring banks entail liquidity, market, and credit risks with some ameliorating factors. Interconnections between banks and their sponsored funds are multiple. These include banks' proprietary investments into their funds; banks' financial commitments to their funds (either contractual or associated with reputational or legal concerns); and funds' holdings of bank liabilities. In Luxembourg, exposures between investment funds and their sponsoring banking groups seem to be limited. For the ten largest funds, banks' proprietary investments represent less than 1 percent of the funds' net asset values (NAV). In turn, banks' lending is less than 0.2 percent of their sponsored funds' NAV and funds' holdings of bank liabilities are low both in terms of their NAV and in terms of the liabilities of their sponsoring banks. While banks' liquidity assistance to their sponsored funds would likely increase under distressed market conditions, the possibility of closing funds' redemptions and suspending NAV calculation represent risk-ameliorating factors. Also, investment fund portfolios seem to be well diversified geographically - roughly 50 (16) percent of portfolios are invested in the Euro Area (U.S.) - and by asset classes. The bulk of the portfolios are in fixed income assets - including deposits - and equities. Likewise, exposures to sovereign risk are diversified, with Germany, U.S., and France constituting the bulk of these securities.

In past few years, increased activity has taken place in structured strategies offered under the UCITS framework. Since the onset of the crisis, demand for exchange traded funds (ETFs) has grown worldwide and so has product complexity. In Luxembourg, more exotic products that provide leverage under UCITS-compliant ETFs have grown quickly, albeit from low levels. Since 2008, these new funds have attracted inflows of about $€ 35$ billion, and Luxembourg domiciled products account for about $1 / 2$ of total alternative UCITS assets and net inflows in 2010. 


\section{Box 2. Evolution of Competitiveness}

Luxembourg's competitiveness has worsened over the past decade despite a small narrowing in the competitiveness gap in 2010. This reflects primarily spillover effects from rapid financial sector growth as well as automatic wage indexation that have not been fully matched by productivity gains. Still, some gains in competitiveness can be seen in unit labor cost-based REERs estimates and the average CGER-based competitiveness gap in 2010. In part, this reflects the unwinding of labor hoarding that had been prevalent in the aftermath of the global financial crisis. But also this reflects a more favorable (larger surplus) outlook for Luxembourg's medium-term current account balance, which is now projected to be closer to its NFA stabilizing level. These gains, however, could easily vanish going forward given the volatility in investment income and financial service exports projections.
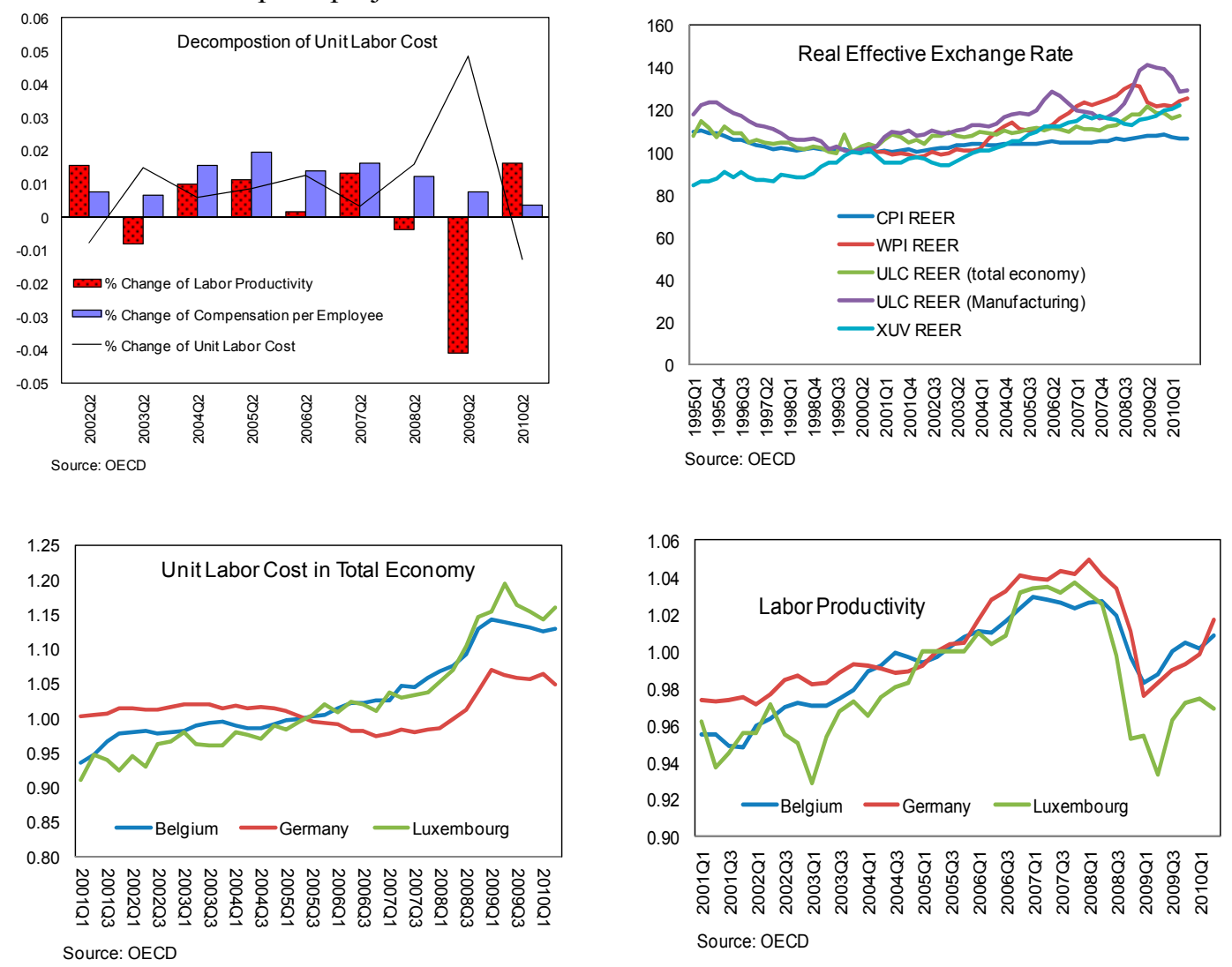

\begin{tabular}{lcc}
\multicolumn{3}{c}{ CGER Assessment of Competitiveness } \\
\hline & Estimate & Estimate \\
& 2010 & 2009 \\
& & \\
\hline & (in percent of GDP) \\
Average competitiveness gap & 3.99 & 5.51 \\
Macroeconomic balance approach & 3.60 & 5.78 \\
Equilibrium real exchange rate approach & 7.37 & 8.70 \\
External stability approach & 0.80 & 2.05 \\
Memorandum items: & & \\
Current account norm & 11.17 & 8.67 \\
Projected current account & 10.80 & 7.00 \\
& & \\
\hline Sources: IFS, IMF staff estimates &
\end{tabular}

Sources: IFS, IMF staff estimates 


\section{OUTLOOK}

7. Export-driven growth is envisaged to slow in 2011. In line with prospects in core Europe, growth is projected to decline from about $3 \frac{1}{2}$ percent in 2010 to about $3 \frac{1}{4}$ percent in 2011. Also, increases in the value of managed portfolios in the investment fund industry are likely to lose steam and banking sector restructuring and deleveraging will likely continue. Domestic demand is expected to strengthen modestly, as growth in private consumption is partially offset by fiscal consolidation, and private investment is projected to remain sluggish as installed capacity has yet to be fully utilized.

\section{Inflation is projected to increase, but a weak labor market will keep a lid on} price pressures in 2011. Driven by global food and fuel developments, headline inflation on average is expected to rise from about $23 / 4$ percent in 2010 to about $3 \frac{1}{2}$ percent in 2011 . Still, core inflation is likely to remain moderate in line with low wage pressures as social partners have agreed to defer automatic wage indexation increases to the fourth quarter of 2011.

\section{While there is a potential for more positive developments, the balance of risks} remains tilted to the downside. Luxembourg could experience stronger growth should global financial markets avoid extreme turbulence and growth in core Europe proves robust. But downside risks prevail. These risks are associated with Luxembourg-based banks' exposure to counterparty and liquidity risks stemming from large cross-border intra-group transactions (Figure 3) and lingering fiscal solvency concerns in the EU periphery. ${ }^{5}$ Holdings of bonds of EU sovereigns are material in some banks and they also face indirect risks from exposures of their parent banking groups, particularly those incorporated in the distressed countries. ${ }^{6}$ Renewed problems in sovereign debt markets or concerns on the financial soundness of parent banks could be transmitted into the domestic banking system. In turn, a sudden loss of investor confidence could trigger outflows from the investment fund industry. While the likelihood that this would affect the local banking sector appears limited, international spillover effects could be amplified given Luxembourg's fund pivotal international role in investment funds.

\section{The authorities broadly agreed, but saw the risks to be more balanced in 2011 .}

While recognizing the heightened uncertainties, the authorities were more sanguine regarding potential upside risks in activity in core Europe. They also noted that domestic demand could be stronger than projected by staff as public investment would increase slightly in nominal terms and private investment is likely to grow, albeit moderately. Regarding downside risks,

\footnotetext{
${ }^{5}$ The interbank positions of Luxembourg-based banks represent about $1 / 2$ of their assets and liabilities, with roughly $2 / 3$ are cross-border intra-group operations.

${ }^{6}$ Luxembourg-based banks' exposure to sovereign risk from Greece, Ireland, Italy, Portugal, and Spain were equivalent to about $1 / 2$ of banks' own resources system wide and exceeded $3 / 4$ of the own resources in a group of institutions jointly accounting for about 14 percent of system assets. As a mitigating factor, about $1 / 2$ of Luxembourg-based banks' exposure to these five countries was to Italy.
} 
the authorities noted that some banks have lowered their direct exposures to EU-periphery sovereign debt, including at the supervisor's request, but recognized the indirect risks stemming from the exposures of their parent banks.

\section{Policy Challenges}

\section{Against this backdrop, Luxembourg faces the challenge of limiting financial sector vulnerabilities while promoting sustainable growth and employment.}

Forthcoming changes in the global regulatory landscape will likely impact Luxembourg's financial sector. In this regard, the consultation focused on preserving financial stability, addressing fiscal challenges, and fostering competitiveness and labor market flexibility.

\section{A. Safeguarding Financial Stability}

\section{The Financial Sector Assessment Program (FSAP) found that the banking sector's main risks reflect their large intra-group exposures and sovereign bond} holdings. Stress test results indicate that parent bank failures could trigger instability in Luxembourg's banking system through counterparty and liquidity risks. Tail risks were associated with a scenario of protracted slowdown in economic activity in core EU, particularly if combined with sovereign debt problems in the EU periphery. In such a scenario, the adverse effects for Luxembourg would be magnified by the size of its financial sector relative to the economy. Fiscal contingencies stemming from banking sector problems could be substantial given the financial sector's size and the lack of a well-defined framework for cross-border bank resolution and burden-sharing mechanisms. Still, public assistance would likely be circumscribed to a handful of institutions that are active in the domestic retail market. ${ }^{7}$

\section{In the investment fund sector, the systemic importance of Luxembourg as a} global hub introduces potential cross-border spillover risks. The likelihood of contagion triggered by large outflows from the investment fund industry to the domestic banking system appears small due to limited balance sheet exposures. However, as observed in other jurisdictions, sudden redemption pressures may entail liabilities for sponsoring banks. More broadly, global investor confidence in Luxembourg's investment fund industry could be affected by perceptions of a tarnished European UCITS brand name. In this regard, it is important for the authorities to monitor rapidly growing UCITS products - particularly leveraged structured products - and ensure that these continue to be sold only to investors that fully comprehend and are able to bear their risks. In turn, a loss of confidence in

\footnotetext{
${ }^{7}$ Staff calculations suggest that, in an extreme adverse scenario, contingent public liabilities stemming from support to these banks could reach 15 percent of GDP. This should not threaten Luxembourg's fiscal sustainability.
} 
Luxembourg's funds may trigger knock-on effects on other European financial systems, and beyond, given the global asset allocation of these funds.

\section{Supervisory effectiveness and consistency with best practices-drawing also on the lessons from the crisis and building on recent reform efforts-would entail further improvements to the financial stability policy framework (Box 3). Specifically, the FSAP recommended:}

- $\quad$ Further enhancing financial sector supervision. The FSAP saw merit in revising the legal statutes of the Commission de Surveillance du Secteur Financier (CSSF) to increase its operational independence from the Ministry of Finance and focus its mandate on the preservation of financial stability. The FSAP also noted undue delays in the presentation and follow-up of on-site findings, due to the relatively modest number of on-site inspectors and gaps in CSSF's internal review and decision making processes. The FSAP also saw merit in strengthening the sanction regime and the enforcement and severity of corrective actions. ${ }^{8}$ In addition, the FSAP recommended clarifying the respective roles of the Central Bank of Luxembourg (BCL) and CSSF as regards liquidity risk supervision.

- $\quad$ Strengthening Luxembourg's financial safety net. As for the institutional setup and toolkit for bank resolution, areas for improvement include allowing for an earlier control of problem banks and facilitating their restructuring on a going-concern basis. The draft law revamping the deposit insurance scheme and introducing ex-ante funding is welcome and awaits the issuance of the corresponding EU directive. Finally, given potentially large liabilities from emergency liquidity assistance to Luxembourg-based banks, safeguarding the BCL's capital remains important.

\section{A number of critical financial policy areas, however, fall beyond the purview of} Luxembourg's authorities. Even though the authorities have taken and, should continue to take, appropriate actions, the presence of large foreign banking groups and sizable crossborder exposures challenge supervision and crisis resolution. Assessing banks' risk profiles at the consolidated level hinges on joint home and host supervisors' work. The authorities are thus encouraged to continue their active involvement in relevant supervisory colleges, which may require additional resources. Regarding the lack of ex-ante burden-sharing arrangements for the resolution of cross-border banks and pending the completion of EU reforms, the authorities should continue to pursue pragmatic steps facilitating international collaboration in this area.

\footnotetext{
${ }^{8}$ For example, in some cases capital add-ons still resulted in regulatory capital requirements well below actual own funds.
} 


\section{Box 3. Main FSAP Recommendations}

\section{B. Institutional Aspects}

- Strengthen the operational independence of the CSSF vis-à-vis the MoF. $S T^{1}$

- Clarify the responsibilities of the BCL and CSSF regarding the supervision of liquidity risk and financial market infrastructures. $S T$

- Formalize a multipartite domestic framework for financial stability and crisis preparedness, providing for specific operational procedures to facilitate crisis prevention and decisive, quick and early intervention. $N T^{2}$

\section{Conduct of Financial Sector Supervision}

- Make the CSSF's oversight procedures and remedial actions more expeditious and effective. $S T$

- Continue to closely monitor exposures to parent banks and take action to limit them, including through formal sanctions when necessary. $S T$

- Continue to increase resources and skills for the supervision of banks, the investment fund industry and financial market infrastructures, to improve risk-focused inspections and enforcement and reduce reliance on external auditors' compliance-oriented work. NT

- Enhance the duties of investment fund depositaries and custodian banks and clarify the investment fund shareholder and ownership rights. NT

\section{Financial Safety Net}

- Strengthen the bank resolution framework, including by providing for earlier control of problem banks and enhanced resolution tools. NT

- Strengthen the deposit insurance scheme through ex ante funding, speedier and automatic payments, the use of funds for bank restructuring, and improved governance. $N T$

- Finalize contingency plans in case of default by CBL, including arrangements to move participants' positions to a solvent intermediary and to continue core functions. NT

\footnotetext{
${ }^{1} S T$ (short-term), or within one year.

${ }^{2} N T$ (near-term), or between one and three years.
}

\section{Luxembourg has made rapid progress in addressing key shortcomings in its} Anti-Money Laundering and Combating the Financing of Terrorism (AML/CFT) framework. The authorities have speedily implemented a remedial action plan to address the numerous shortcomings noted in the FATF's February 2010 review. Luxembourg has thus been removed from the International Cooperation Review Group process recently. Going 
forward, the effectiveness of the new measures will be monitored in the regular FATF follow-up process.

17. The authorities broadly agreed with staff's assessment and policy advice. They acknowledged that cross-border contagion from parent banks is a major risk to Luxembourgbased banks. The authorities stressed that they monitor these risks closely and remain ready to take further actions on a case-by-case basis. Also, they noted that a CSSF circular is being prepared that will require stronger risk management practices, especially as relates to arm's length relationships between local subsidiaries and their foreign parent banks. More broadly, the authorities stressed ongoing work in the context of EU supervisory colleges, and reiterated their commitment to enhance cross-border collaboration relating to financial supervision and crisis resolution. They also noted the recent preparation of a draft law aimed at strengthening the CSSF's sanctioning and enforcement powers as well as their intention to adjust the legal framework in order to better guarantee the CSSF's operational independence - thereby addressing two key FSAP recommendations. The authorities indicated that they intend to move ahead with the approval of the new law on Luxembourg's deposit insurance scheme later this year-should the issuance of the new EU directive be further delayed — and increase the BCL's capital.

\section{B. Fiscal Consolidation and Pension Reform}

18. The 2011 budget has appropriately initiated fiscal consolidation. The budget targets cutting the deficit from 13/4 percent of GDP to about 1 percent, with the consolidation being predominately expenditure-based. A cap on public investment to 2009 levels accounts for about $2 / 3$ of the adjustment. On the revenue side, the budget includes measures directed at upper-income households and, to a lesser extent, corporations. Specifically, a new crisis tax of 0.8 percent on personal income has been levied on all households earning more than the minimum wage. Also, the solidarity tax and the top marginal personal income tax rate have been increased (Table 4). While fiscal consolidation is fitting to the stage of the cycle, should economic activity slow more than expected, automatic stabilizers should be allowed to operate up to the Maastricht limit.

\section{Current expenditure compression-particularly social transfers and the public} sector wage bill - should be central to fiscal efforts. The brunt of the 2011 adjustment falls, however, on public investment, with further reductions of about $3 / 4$ percent of GDP on average in the next five years. The budget's tight investment envelop could serve to improve the prioritization and efficiency of public investment projects in the short run. But sustained declines in public investment may harm growth prospects and there will thus be a need to replace the cap with current expenditure cuts over time.

20. Going forward, fiscal prospects are clouded by the lack of pension reform and uncertainties associated with a changing financial regulatory environment. Luxembourg faces the largest age-related expenditure increases in the EU. Official projections show that 
age-related expenditures are set to double to 40 percent of GDP by 2060 , of which $3 / 4$ stem from old-age pension benefits. A surge in age-related spending is projected from 2020 onwards associated with accrued pension benefits combined with an aging population (Figure 4). Official projections foresee pension reserves to be depleted by about 2035 and continue deteriorating sharply thereafter. In addition, forthcoming financial regulatory changes may serve to erode Luxembourg's medium-run tax revenues.

\section{In this regard, the authorities have been pursuing a two-pronged strategy. Specifically,}

- $\quad$ Stop-gap measures to contain age-related spending starting in 2011. They have divided the 2-percent pension benefit increase scheduled for 2011 into two tranches, with the second tranche delayed until January 2012 (lowering expenditure by about 0.1 percent of GDP in 2011). On the health care front, increases in co-payments and contributions, combined with revisions to hospital charges were approved by parliament in late 2010. ${ }^{9}$ The authorities have also introduced a flat $1 \frac{1 / 4}{4}$ percent health insurance premium for workplace injuries replacing the existing risk-based scale, in effect increasing the premium on the financial sector. ${ }^{10}$ This has been part of a broader health care system reform that envisages a welcome establishment of a binding twoyear budget for hospitals.

- $\quad$ Reaffirming their medium-term fiscal target of a balance in 2014. Abstracting from fiscal consequences of aging, this would stabilize medium-term debt at about 30 percent of GDP.

\section{There remains nonetheless a pressing need to articulate a lasting fiscal} consolidation strategy. On current policies, the projected fiscal balance in 2014 would fall short of the authorities' target by about $1 \frac{1}{2}$ percent of GDP, including the need to eliminate the investment cap and replace transitory revenue measures. The authorities have not detailed fiscal consolidation measures to achieve their medium-term target. In this regard, establishing a medium-term budgetary framework could help prioritized public spending. While pursuing potential efficiency gains in other current spending, the emphasis should be on rationalizing social transfers and subsidies that are generous even by European standards (Figure 5). A comprehensive review of social transfers and subsidies-needed also for social justice - should proceed to improve their effectiveness, discard programs that are no longer justified, and ameliorate adverse work incentives. Besides the aforementioned room to cut

\footnotetext{
${ }^{9}$ The 2011 budget does not reflect this adjustment estimated to be about $1 / 4$ percent of GDP ( $€ 107$ million).

${ }^{10}$ The increase in premiums paid by the financial sector is equivalent to roughly 1 percentage point of their overall personnel expenses ( 0.1 percent of GDP)
} 
current spending, tax increases also should be viewed with caution in current global financial environment.

\section{Fiscal sustainability will ultimately hinge on reforming the pension system and} implementing recently-approved healthcare reforms. Notwithstanding its current surplus, Luxembourg's old-age pension system runs one of the EU's largest actuarial deficits. In addition, the large and volatile share of cross-border workers in the labor force, and their current role as net pension contributors, introduces an additional element of uncertainty in the system's long-run finances. In the context of tripartite discussions, the authorities have proposed a number of parametric changes to old-age pensions, notably increasing the effective retirement age. Implementing these proposals would go a long way to protect Luxembourg's old-age pension system and putting these in place early would facilitate a desirable phasing in of reforms. In addition, limiting pension benefit indexation to no more than cost of living adjustments will be needed to address the burden on the system's finances from existing retirees and entitlements. On the health care front, recent reforms are welcome and should be expeditiously implemented. Moving ahead promptly on both fronts can avoid the need for radical measures as the peak of the fiscal impact of aging nears.

\section{While agreeing that fiscal consolidation was appropriate, the authorities were} reluctant to allow automatic stabilizers to operate fully, should growth slow more than

expected. Besides the negligible fiscal multipliers in a small open economic, political realities introduce an asymmetry in the cycle whereby it was exceedingly difficult to consolidate during an upswing. They stressed nonetheless their commitment to achieve a balance by 2014 . The authorities concurred with the need to replace the investment cap with current expenditure cuts and rein in social transfers. In this connection, they will conduct a comprehensive review of the existing social programs to assess their effectiveness and minimize adverse work incentives. They noted ongoing work to reform budget procedures and address the public wage bill, and they did not see the need for further tax increases.

\section{They also broadly shared concerns regarding aging-related expenditure}

pressures. The authorities noted an increasing awareness throughout society regarding the need to reform old-age pensions. They have publicly announced their intention to introduce parametric reforms to better align benefits and contributions by extending the number of working years required to receive a full pension. Regarding unfunded liabilities arising from existing retirees and entitlements, the authorities were still formulating their policies but noted that, if needed, social contributions could be raised. The authorities reiterated their commitment to continue looking for a set of parametric adjustment that would place the system on a firm financial footing, but discussions with social partners will remain difficult. 


\section{Long-Run Challenges to Financial-Sector Led Growth and Competitiveness}

\section{Luxembourg's financial-sector based growth model will be challenged by} forthcoming changes to the international regulatory framework. In light of the level and quality of banks' capital, the new international capital regime is unlikely to pose major difficulties for Luxembourg-based banks. While forthcoming changes and their implementation schedules have yet to finalized, changes to the liquidity regime - critically if intra-group exposures are subject to tighter restrictions - could potentially have a significant impact on Luxembourg-based banks' ability to serve as liquidity conduits in the medium term. The financial sector, in particular the banking sector, will also continue facing headwinds from ongoing global deleveraging and an international push to harmonize taxation and enhance transparency.

\section{The economy's ability to adapt to a changing environment will hinge on} regaining lost competitiveness, fostering real wage flexibility, and addressing mismatched skills. Rapid growth of the financial sector has hurt competitiveness by pushing up wages throughout the economy without corresponding productivity gains (Box 2). This has been amplified by automatic backward-looking wage indexation and increases in minimum wages. The adverse impact of losses in competitiveness has been particularly evident in goods exports. ${ }^{11}$ In this regard, the authorities are encouraged, together with social partners, to explore ways to limit the adverse effects of wage indexation - including by excluding food and fuel prices from the reference index-with a view of eliminating indexation in the medium term. In addition, there is a need to bolster the education system to ensure that local workers acquire and continue developing skills demanded by the labor market. In this regard,

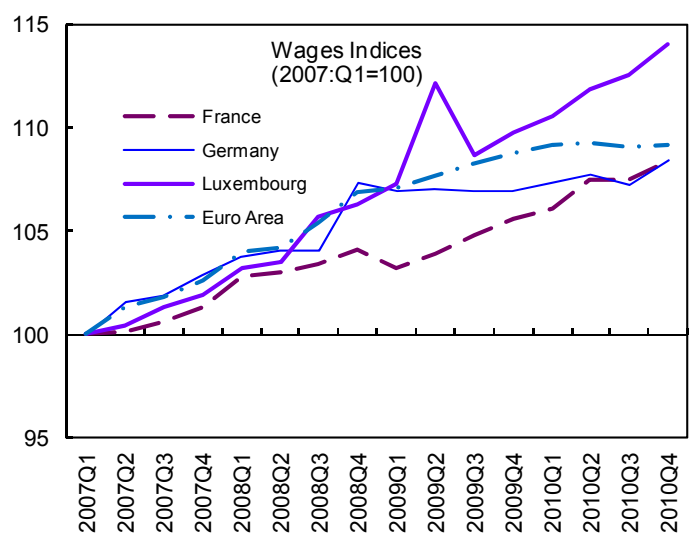

Sources: EUROSTAT, IMF staff calculation the system of direct transfers-geared at lowering poverty and income inequality — should be revamped to limit its adverse work incentives and support human capital formation and develop skills demanded by the labor market.

\section{The authorities broadly agreed with the challenges facing Luxembourg and} recognized the need to further reform the economy. They were nonetheless guardedly optimistic regarding Luxembourg financial center's medium-term prospects given the

\footnotetext{
${ }^{11}$ Recently, backward wage indexation has been shown to significantly increase wage rigidity (Lunnemann and Wintr, 2010). Annex III provides empirical evidence of the adverse impact of wage rigidity on price competitiveness in Luxembourg, particularly in manufacturing.
} 
availability of highly-qualified professionals and supporting infrastructure. Indeed, the authorities noted that the overall decline in bank balance sheets experienced so far had been driven by about only 40 percent of the banks, with most banks experiencing increases. The authorities recognized that automatic wage indexation has eroded competitiveness, but stressed that competitiveness trends differed across sectors, with manufacturing suffering the most. In this regard, they noted that wage increases will be reined in by the postponement in wage indexation this year and by the agreement to try to avoid another wage indexation tranche should it be triggered in less than 12 months. Also, the authorities viewed favorably dropping fuel prices from the reference index and stressed their intention to revisit employment support programs to assess their effectiveness and reduce adverse effects on work incentives.

\section{Staff Appraisal}

\section{The challenge facing Luxembourg is to continue limiting financial sector} vulnerabilities while promoting sustainable growth and employment. The financial sector has stabilized but the banking sector remains vulnerable to risks associated with large intra-group exposures and sovereign bond holdings. The economy has begun its recovery but growth will likely slow in 2011 and remain below its pre-crisis pace. Headline inflation will continue to increase although increases in core inflation will likely remain moderate reflecting delays in wage indexation and slack in the economy. The unemployment rate has risen and stabilized despite gradual increases in employment growth and labor support programs.

\section{For the financial sector, the challenge entails improving the financial stability} policy framework. The FSAP stressed that this will require further enhancing financial sector supervision by increasing the operational independence of supervisors and strengthening on-site supervision. Exposures to parent banks should also continue to be closely monitored, and the authorities should take further actions to limit such exposures when necessary. In addition, Luxembourg's financial safety net should be strengthened by facilitating an earlier control and restructuring of problem banks on a going-concern basis and allowing the use of deposit insurance funds in bank resolution on least-cost principle. Should there be further delays in the new EU directive on deposit guarantees, Luxembourg would benefit from reforming its deposit guarantee system as envisaged in the draft law.

\section{A number of critical financial policy areas, however, fall beyond the purview of}

the Luxembourg authorities. Even though the authorities have taken and should continue to take appropriate actions, the presence of large foreign banking groups and sizable crossborder exposures challenge supervision and crisis resolution. The authorities are thus encouraged to continue their active involvement in relevant supervisory colleges, which may entail additional resources. Lacking ex-ante burden-sharing arrangements for the resolution of cross-border banks and pending the completion of EU reforms, the authorities should also continue to pursue pragmatic steps to facilitate international collaboration in this area. 


\section{On the fiscal front, the challenge involves implementing sustainable}

consolidation. With the recovery taking hold, the expenditure-based fiscal consolidation focus of the 2011 budget is appropriate. While the budget's investment cap can help to prioritize projects in light of competing demands on the public purse in the short run, there will be a need to replace the cap with current spending cuts to bolster growth prospects. Regardless, should growth slow more than expected automatic stabilizers should be allowed to operate up to the Maastricht limit. Care will be needed, nonetheless, to ensure that a purely cyclical change in the deficit does not become structural because of policy decisions that lead to an entrenchment of cyclical spending.

\section{In this regard, there is a pressing need to rationalize current spending. This will} require formulating specific measures to replace temporary measures, safeguard public investment, and achieve the authorities' medium-term fiscal target. The focus must center on rationalizing social transfers and subsidies while curtailing other current spending, including increases in the public sector wage bill. Expenditure prioritization can be supported by establishing a full-fledged medium-term budgetary framework with binding multi-year expenditure ceilings.

\section{In addition, reforming the old-age pension system is long overdue. Fiscal} consolidation cannot substitute for reforms given the magnitude of aging-related expenditure increases. Parametric reforms are needed to gradually increase the effective and statutory retirement ages to reflect life expectancy gains and align contributions and benefits. This will require working longer to earn a full pension and, to address the inherited burden on the system from existing retirees and entitlements, limiting pension indexation to no more than cost of living adjustments. Also, the authorities are urged to expeditiously implement recently approved health care reforms to ensure the system's sustainability. Putting in place reforms early will be desirable to facilitate phasing-in adjustments, and establishing periodic automatic reviews of the social security's financial viability can enable timely adjustments in light of future economic and demographic developments.

\section{More broadly, sustainable growth and employment hinge on boosting} competitiveness and promoting labor market flexibility. Success in adapting to the changing global financial environment will entail fostering a competitive and flexible economy. Besides continued attention to infrastructure and education, it is important to revamp the system of social transfers and subsidies in order to limit adverse work incentives, address mismatched skills, and support human capital investment. Also, even though in the medium term eliminating wage indexation remains necessary, the authorities are urged to exclude food and fuel prices from the reference index. In the short term, there is a continuing need to curb nominal wage increases to avoid eroding competitiveness.

\section{It is recommended that the next Article IV consultation with Luxembourg be held on the standard 12-month cycle.}


Table 1. Luxembourg: Basic Data, 2007-12

\begin{tabular}{|c|c|c|c|c|c|c|}
\hline & \multirow[b]{2}{*}{2007} & \multirow[b]{2}{*}{2008} & \multirow[b]{2}{*}{2009} & \multirow{2}{*}{$\begin{array}{l}\text { Prel. } \\
2010\end{array}$} & \multicolumn{2}{|c|}{ Proj. } \\
\hline & & & & & 2011 & 2012 \\
\hline \multicolumn{7}{|l|}{ Real Economy (change in percent) } \\
\hline Gross domestic product & 6.6 & 1.4 & -3.6 & 3.5 & 3.2 & 3.3 \\
\hline Total domestic demand & 6.1 & 3.0 & -6.4 & 3.1 & 4.3 & 3.4 \\
\hline Private consumption & 3.3 & 4.7 & 0.2 & 2.0 & 3.8 & 2.9 \\
\hline Public consumption & 2.8 & 2.7 & 4.6 & 3.1 & 2.5 & 2.5 \\
\hline Gross investment & 12.5 & 0.7 & -23.2 & 5.1 & 7.1 & 4.9 \\
\hline Foreign balance $1 /$ & 1.9 & -1.4 & 1.6 & 0.9 & 1.2 & 0.8 \\
\hline Exports of goods and nonfactor services & 9.1 & 6.6 & -8.2 & 6.3 & 4.6 & 5.1 \\
\hline Imports of goods and nonfactor services & 9.3 & 8.5 & -10.2 & 6.7 & 4.6 & 5.4 \\
\hline \multicolumn{7}{|c|}{ Employment and unemployment (thousands, unless indicated) } \\
\hline Resident labor force & 217.3 & 223.6 & 228.7 & 232.1 & 235.8 & 239.3 \\
\hline Unemployed & 9.6 & 9.9 & 13.2 & 14.0 & 13.8 & 13.7 \\
\hline (As a percent of total labor force) & 4.4 & 4.4 & 5.8 & 6.0 & 5.9 & 5.7 \\
\hline Resident employment & 207.7 & 213.7 & 215.5 & 218.1 & 222.0 & 225.6 \\
\hline (change in percent) & 2.5 & 2.9 & 0.8 & 1.2 & 1.8 & 1.7 \\
\hline Cross-border workers (net) & 125.4 & 135.1 & 136.6 & 140.0 & 141.8 & 143.5 \\
\hline Total employment & 333.0 & 348.8 & 352.1 & 358.1 & 363.7 & 369.2 \\
\hline (Change in percent) & 4.5 & 4.7 & 0.9 & 1.7 & 1.6 & 1.5 \\
\hline \multicolumn{7}{|l|}{ Prices and costs (change in percent) } \\
\hline CPI (harmonized), p.a. & 2.7 & 4.1 & 0.0 & 2.8 & 3.7 & 1.7 \\
\hline CPI (national definition), p.a. & 2.3 & 3.4 & 0.4 & 2.3 & 3.4 & 1.7 \\
\hline Average nominal wage growth 2 / & 3.7 & 2.1 & 1.8 & 1.8 & 2.3 & 2.5 \\
\hline Nominal unit labor costs $2 /$ & -1.7 & 1.3 & 7.1 & -5.1 & 2.3 & 2.5 \\
\hline \multicolumn{7}{|l|}{ Public finances (percent of GDP) } \\
\hline General government revenues & 39.8 & 39.8 & 41.3 & 39.5 & 36.4 & 36.2 \\
\hline General government expenditures & 36.2 & 36.9 & 42.2 & 41.2 & 37.3 & 36.9 \\
\hline General government balance & 3.7 & 3.0 & -0.9 & -1.7 & -0.9 & -0.6 \\
\hline General government gross debt & 6.7 & 13.6 & 14.5 & 16.5 & 17.3 & 18.7 \\
\hline \multicolumn{7}{|l|}{ Balance of Payments (percent of GDP) } \\
\hline Current account & 10.1 & 5.3 & 6.9 & 7.8 & 11.5 & 11.3 \\
\hline Balance on goods & -9.3 & -10.9 & -8.0 & -9.6 & -9.1 & -9.2 \\
\hline Balance on services & 53.0 & 50.3 & 47.1 & 54.7 & 50.2 & 46.8 \\
\hline Net factor income & -29.7 & -29.6 & -29.5 & -35.7 & -28.0 & -24.7 \\
\hline Balance on current transfers & -3.9 & -4.5 & -2.7 & -1.6 & -1.6 & -1.6 \\
\hline \multicolumn{7}{|l|}{ Exchange rates $3 /$} \\
\hline U.S. dollar per euro & 1.4 & 1.5 & 1.4 & 1.3 & $\ldots$ & $\ldots$ \\
\hline percent change & 9.2 & 7.4 & -5.4 & -9.8 & $\ldots$ & $\ldots$ \\
\hline Nominal effective rate $(2005=100)$ & 101.5 & 103.9 & 104.9 & 102.1 & $\ldots$ & $\ldots$ \\
\hline percent change & 1.3 & 2.3 & 1.0 & -1.7 & $\ldots$ & $\ldots$ \\
\hline Real effective rate (CPI based; $2005=100$ ) & 101.5 & 103.5 & 104.5 & 101.8 & $\ldots$ & $\ldots$ \\
\hline percent change & 0.9 & 2.0 & 1.0 & -1.6 & $\ldots$ & $\ldots$ \\
\hline \multicolumn{7}{|l|}{ Interest rates 3 / } \\
\hline Government bond yield & 4.5 & 4.2 & 4.2 & 3.3 & $\ldots$ & .. \\
\hline
\end{tabular}

Memorandum items: Land area $=2,586$ square kilometers; population in $2009=502$ thousand; GDP per capita $=€ 75,771$.

Sources: Data provided by the authorities; IMF, WEO database; and IMF staff calculations.

$1 /$ Contribution to GDP growth.

2/ Overall economy.

3/ For 2010, data refer to December. 
Table 2. Luxembourg: General Government Operations 2009-15

\begin{tabular}{|c|c|c|c|c|c|c|c|}
\hline & \multirow[b]{2}{*}{2009} & \multirow{2}{*}{$\frac{\text { Prel. }}{2010}$} & \multicolumn{5}{|c|}{ Proj } \\
\hline & & & 2011 & 2012 & 2013 & 2014 & 2015 \\
\hline & \multicolumn{7}{|c|}{ (In percent of GDP) } \\
\hline Revenue & 41.3 & 39.5 & 36.4 & 36.2 & 36.2 & 36.2 & 36.2 \\
\hline Tax revenue & 25.6 & 24.7 & 22.3 & 22.2 & 22.2 & 22.2 & 22.3 \\
\hline Indirect taxes & 11.7 & 11.4 & 10.2 & 10.1 & 10.1 & 10.1 & 10.1 \\
\hline Direct taxes & 13.8 & 13.3 & 12.1 & 12.1 & 12.0 & 12.1 & 12.1 \\
\hline Social security contributions & 12.0 & 11.4 & 10.6 & 10.5 & 10.4 & 10.3 & 10.2 \\
\hline Other revenue & 3.6 & 3.4 & 3.5 & 3.5 & 3.6 & 3.7 & 3.7 \\
\hline Expenditure & 42.2 & 41.2 & 37.3 & 36.9 & 36.9 & 36.4 & 36.1 \\
\hline Current expenditure & 40.1 & 38.7 & 36.0 & 35.6 & 35.6 & 35.1 & 34.8 \\
\hline Wages and salaries & 7.9 & 7.7 & 7.2 & 7.0 & 7.0 & 7.0 & 6.9 \\
\hline Goods and services & 3.6 & 3.5 & 3.2 & 3.2 & 3.2 & 3.1 & 3.1 \\
\hline Social transfers and pensions & 20.6 & 19.7 & 18.0 & 17.8 & 17.8 & 17.6 & 17.4 \\
\hline Social security benefits & 17.7 & 16.9 & 15.6 & 15.4 & 15.4 & 15.2 & 15.1 \\
\hline Interest payments & 0.4 & 0.4 & 0.5 & 0.7 & 0.8 & 1.0 & 1.1 \\
\hline Other current expenditure & 7.6 & 7.3 & 7.1 & 6.9 & 6.8 & 6.5 & 6.3 \\
\hline Net acquisition of nonfinancial assets & 2.1 & 2.6 & 1.3 & 1.3 & 1.3 & 1.2 & 1.2 \\
\hline Overall balance & -0.9 & -1.7 & -0.9 & -0.6 & -0.7 & -0.1 & 0.1 \\
\hline
\end{tabular}

Source: Luxembourg Statistical Office and Staff Estimates. 
Table 3. Luxembourg: External Current Account, 2009-15

\begin{tabular}{|c|c|c|c|c|c|c|c|}
\hline & \multirow[b]{2}{*}{2009} & \multirow{2}{*}{$\frac{\text { Prel. }}{2010}$} & \multicolumn{5}{|c|}{ Proj. } \\
\hline & & & 2011 & 2012 & 2013 & 2014 & 2015 \\
\hline Current account & 6.9 & 7.8 & 11.5 & 11.3 & 11.2 & 11.1 & 10.8 \\
\hline Balance on goods and services & 39.1 & 45.1 & 41.1 & 37.6 & 35.1 & 32.6 & 29.9 \\
\hline Trade balance & -8.0 & -9.6 & -9.1 & -9.2 & -9.4 & -9.6 & -9.9 \\
\hline Merch exports & 29.3 & 30.5 & 29.2 & 29.5 & 30.0 & 30.6 & 31.1 \\
\hline Merch imports & 37.4 & 40.1 & 38.3 & 38.7 & 39.4 & 40.2 & 41.0 \\
\hline Balance on services & 47.1 & 54.7 & 50.2 & 46.8 & 44.4 & 42.2 & 39.8 \\
\hline Services exports & 112.0 & 122.5 & 114.9 & 112.1 & 112.4 & 113.6 & 114.5 \\
\hline Services imports & 64.9 & 67.8 & 64.7 & 65.2 & 67.9 & 71.4 & 74.8 \\
\hline Net factor income & -29.5 & -35.7 & -28.0 & -24.7 & -22.3 & -19.9 & -17.5 \\
\hline Compensation of employees, net & -16.7 & -15.9 & -14.3 & -13.7 & -13.2 & -12.7 & -12.2 \\
\hline Compensation of employees, credit & 3.0 & 2.8 & 2.6 & 2.6 & 2.6 & 2.5 & 2.5 \\
\hline Compensation of employees, debit & 19.7 & 18.7 & 16.9 & 16.3 & 15.7 & 15.2 & 14.7 \\
\hline Investment income, net & -12.7 & -19.8 & -13.7 & -11.0 & -9.1 & -7.3 & -5.3 \\
\hline Investment income, credit & 279.6 & 251.8 & 228.1 & 219.2 & 212.1 & 204.7 & 197.8 \\
\hline Investment income, debit & 292.4 & 271.6 & 241.7 & 230.2 & 221.1 & 212.0 & 203.1 \\
\hline Balance on current transfers & -2.7 & -1.6 & -1.6 & -1.6 & -1.6 & -1.6 & -1.6 \\
\hline
\end{tabular}

Source: Statec and IMF staff projections. 
Table 4. Estimated Effect of Fiscal Consolidation 2011-14 1/

\begin{tabular}{|c|c|c|c|c|c|c|c|c|}
\hline & 2011 & 2012 & 2013 & 2014 & 2011 & 2012 & 2013 & 2014 \\
\hline & \multicolumn{4}{|c|}{ In percent of GDP } & \multicolumn{4}{|c|}{ In million euro } \\
\hline Expenditures & -1.1 & -1.1 & -1.1 & -1.2 & -508.5 & -540.8 & -584.2 & -660.2 \\
\hline Central administration costs & -0.1 & -0.1 & -0.1 & 0.0 & -34.0 & -34.6 & -26.0 & -26.5 \\
\hline Allowances for students & -0.1 & -0.1 & -0.1 & -0.1 & -33.0 & -34.0 & -34.0 & -35.0 \\
\hline Adjustment to pensions & -0.1 & 0.0 & 0.0 & 0.0 & -38.5 & -6.7 & -4.6 & -6.2 \\
\hline Public transportation grants & 0.0 & 0.0 & 0.0 & 0.0 & -5.0 & -5.0 & -15.0 & -20.0 \\
\hline Subsidies to firms & 0.0 & 0.0 & 0.0 & 0.0 & -17.0 & -19.0 & -19.0 & -19.0 \\
\hline Cap in public investment & -0.8 & -0.9 & -0.9 & -1.0 & -361.0 & -421.5 & -485.6 & -553.5 \\
\hline Capital transfers & 0.0 & 0.0 & 0.0 & 0.0 & -20.0 & -20.0 & 0.0 & 0.0 \\
\hline Revenues & 0.4 & 0.4 & 0.2 & 0.2 & 166.0 & 184.0 & 111.0 & 114.0 \\
\hline Increase of top marginal PIT rate & 0.1 & 0.1 & 0.1 & 0.1 & 27.0 & 40.0 & 41.0 & 42.0 \\
\hline Increase in solidarity tax & 0.1 & 0.1 & 0.1 & 0.1 & 66.0 & 69.0 & 70.0 & 72.0 \\
\hline Households & 0.1 & 0.1 & 0.1 & 0.1 & 52.0 & 54.0 & 55.0 & 57.0 \\
\hline Firms & 0.0 & 0.0 & 0.0 & 0.0 & 14.0 & 15.0 & 15.0 & 15.0 \\
\hline Crisis tax (0.8 percent) & 0.2 & 0.2 & 0.0 & 0.0 & 73.0 & 75.0 & 0.0 & 0.0 \\
\hline Total fiscal adjustment & 1.5 & 1.5 & 1.4 & 1.4 & 674.5 & 724.8 & 695.2 & 774.2 \\
\hline \multicolumn{9}{|l|}{ Public sector balance } \\
\hline Without austerity measures & -2.3 & -2.1 & -2.1 & -1.7 & $-1,087.7$ & $-1,043.3$ & $-1,080.4$ & -917.5 \\
\hline With austerity measures & -0.9 & -0.7 & -0.8 & -0.3 & -413.2 & -318.5 & -385.2 & -143.3 \\
\hline \multicolumn{9}{|l|}{ Memo: } \\
\hline GDP Growth & 3.5 & 3.2 & 3.2 & 3.2 & $\ldots$ & $\ldots$ & $\ldots$ & \\
\hline Nominal GDP & $\ldots$ & $\ldots$ & $\ldots$ & $\ldots$ & 46,434 & 48,818 & 51,125 & 53,583 \\
\hline
\end{tabular}

Source: Ministry of Finance and IMF staff calculations.

1/ Measures announced by the government on May 5, 2010 and included in the 2011 budget.

2/ Projections of the 11th Update of the Stability and Growth Pact (January 2010). 
Table 5. Luxembourg: Financial Soundness Indicators 2007-10 1/ (In Percent)

\begin{tabular}{|c|c|c|c|c|c|c|}
\hline & 2007 & 2008 & Jun-09 & Dec-09 & Jun-10 & Dec-10 \\
\hline \multicolumn{7}{|l|}{ Capital Adequacy } \\
\hline Regulatory capital to risk-weighted assets & 14.3 & 15.4 & 17.1 & 18.9 & 18.0 & 17.0 \\
\hline Regulatory Tier 1 capital to risk-weighted assets & 12.2 & 13.0 & 14.8 & 17.0 & 16.0 & 15.0 \\
\hline Capital to assets & 4.0 & 4.0 & 5.0 & 5.5 & 5.0 & 5.0 \\
\hline \multicolumn{7}{|l|}{ Profitability And Efficiency } \\
\hline Return on assets & 0.8 & 0.2 & 0.7 & 0.6 & 0.7 & 0.7 \\
\hline Return on equity & 20.4 & 5.5 & 14.4 & 11.6 & 13.0 & 13.0 \\
\hline Interest margin to gross income & 27.0 & 37.7 & 37.7 & 36.5 & 29.0 & 31.0 \\
\hline Trading income to total income & 1.9 & -8.9 & 6.4 & 6.0 & 1.0 & -1.0 \\
\hline Noninterest expenses to gross income & 50.5 & 56.2 & 56.0 & 56.3 & 61.0 & 64.0 \\
\hline Personnel expenses to noninterest expenses & 37.9 & 35.7 & 40.0 & 38.7 & 41.0 & 36.0 \\
\hline \multicolumn{7}{|l|}{ Asset Quality And Structure } \\
\hline Residential real estate loans to total loans & 2.1 & 2.2 & 2.5 & 2.8 & 3.0 & 3.0 \\
\hline Household debt to GDP & 44.0 & 45.0 & 48.0 & 50.0 & 52.0 & 54.0 \\
\hline $\begin{array}{l}\text { Nonperforming large exposures to total large exposures } 2 / \\
\text { Sectoral distribution of loans (in \% of total loans) }\end{array}$ & 0.4 & 0.6 & 0.8 & 0.7 & 0.6 & 0.2 \\
\hline Residents & 22.5 & 26.6 & 26.4 & 23.4 & 27.0 & 22.0 \\
\hline Deposit Takers & 11.7 & 10.7 & 12.6 & 9.8 & 8.0 & 7.0 \\
\hline Central Bank & 1.5 & 6.4 & 2.7 & 2.3 & 6.0 & 2.0 \\
\hline Other Financial Corporations & 4.7 & 4.2 & 5.0 & 4.8 & 6.0 & 6.0 \\
\hline General Government & 0.3 & 0.4 & 0.4 & 0.4 & 0.4 & 0.5 \\
\hline Nonfinancial Corporations & 1.8 & 2.4 & 2.6 & 2.6 & 2.0 & 2.0 \\
\hline Other Domestic Sectors & 2.5 & 2.6 & 3.0 & 3.4 & 3.0 & 4.0 \\
\hline Non Residents & 77.5 & 73.4 & 74.0 & 77.0 & 73.0 & 78.0 \\
\hline \multicolumn{7}{|l|}{ Liquidity } \\
\hline Liquid assets to total assets & 50.0 & 59.0 & 56.0 & 55.9 & 54.0 & 56.0 \\
\hline Liquid assets to short-term liabilities & 61.0 & 67.8 & 63.6 & 64.7 & 64.0 & 66.0 \\
\hline Customer deposits to total (non interbank) loans & 165.0 & 134.7 & 139.6 & 137.5 & 120.0 & 131.0 \\
\hline \multicolumn{7}{|l|}{ Foreign Exchange } \\
\hline Foreign currrency denominated loans to total loans & 34.5 & 30.2 & 28.7 & 28.0 & 29.0 & 30.0 \\
\hline Foreign currency denominated liabilities to total liabilities & 33.8 & 29.1 & 28.6 & 28.8 & 32.0 & 33.0 \\
\hline Net open foreign exchange to capital & 3.1 & 1.6 & -0.4 & -0.6 & 0.2 & 0.3 \\
\hline
\end{tabular}

Source: Central Bank of Luxembourg.

$1 /$ There is a break in the series in 2009 due to the adoption of IAS and IFRS in 2008.

$2 /$ Change in the underlying reporting instructions as of 31/12/2010. 
Figure 1. Luxembourg: Consumption Developments

Consumption has gradually recovered,

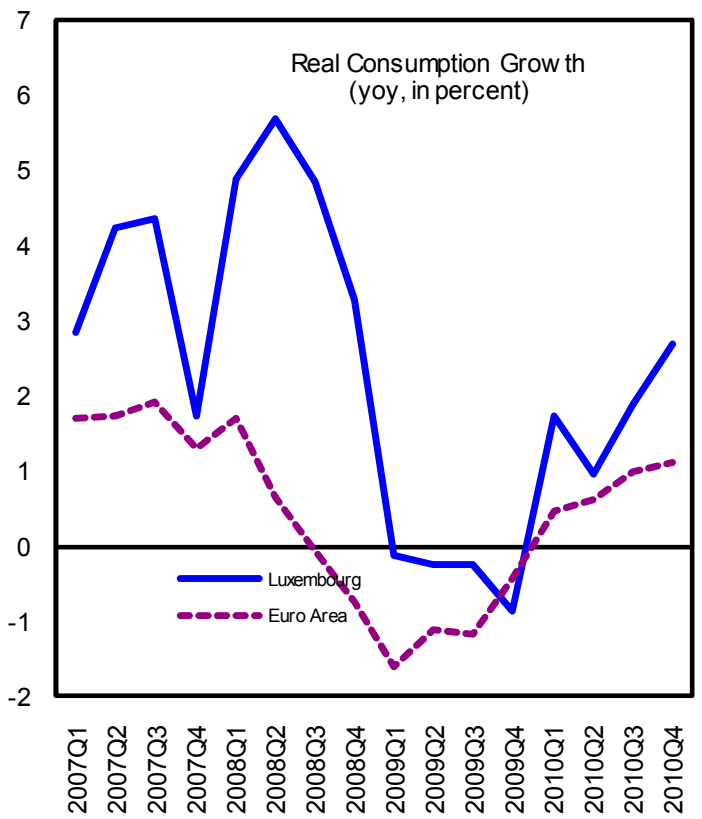

... robust house prices,

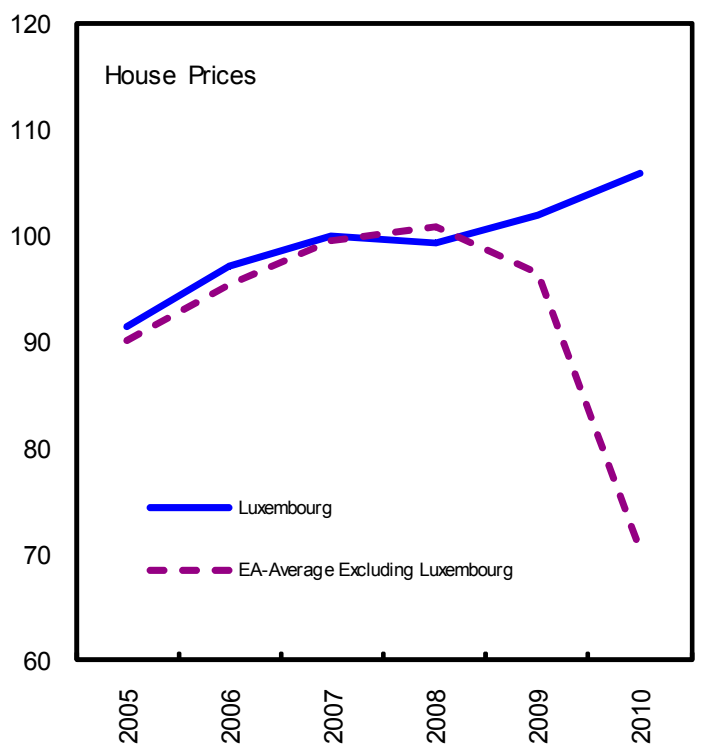

...partly due to improved consumer confidence,

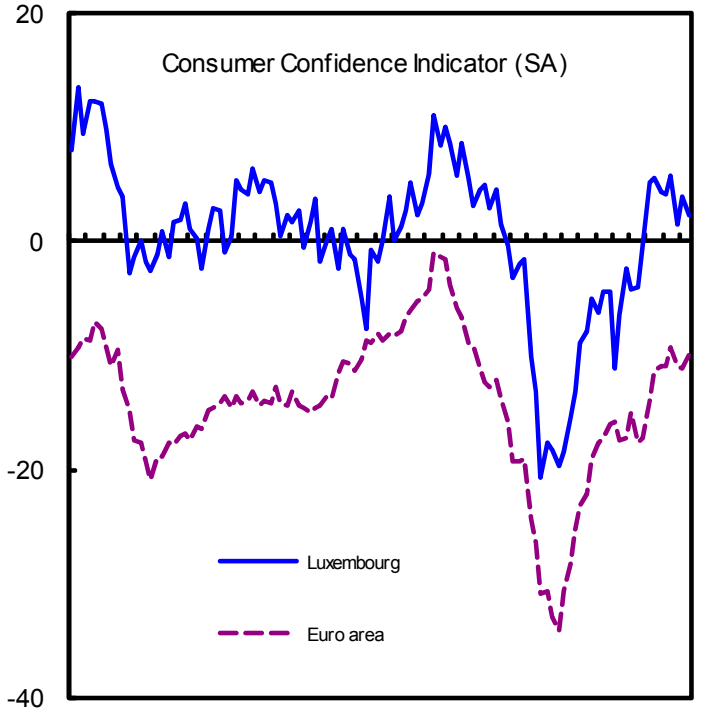

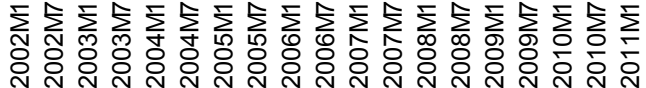

... and moderate mortgage loan indebtness.

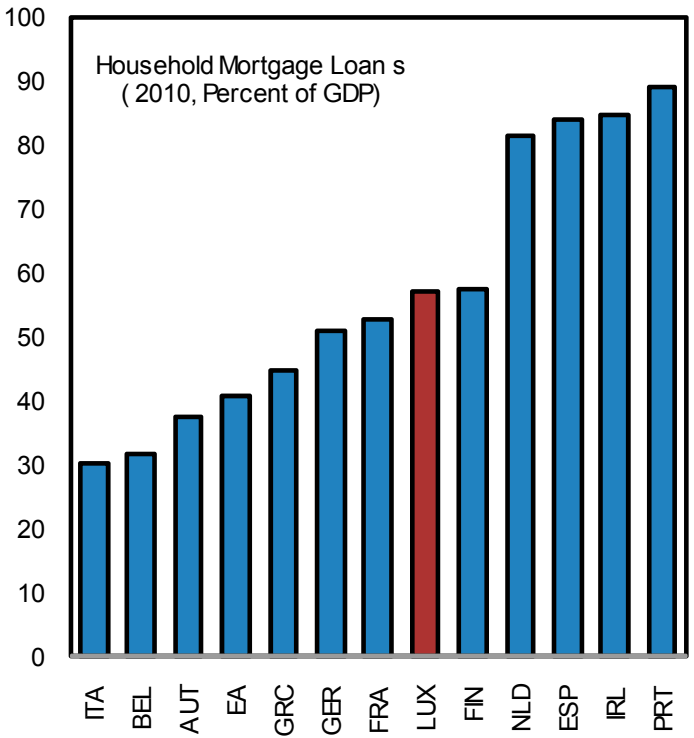

Sources: Haver, BIS, Statec 
Figure 2. Luxembourg: Inflation and Labor Market Developments

(Annual Growth Rates, unless otherwise indicated)
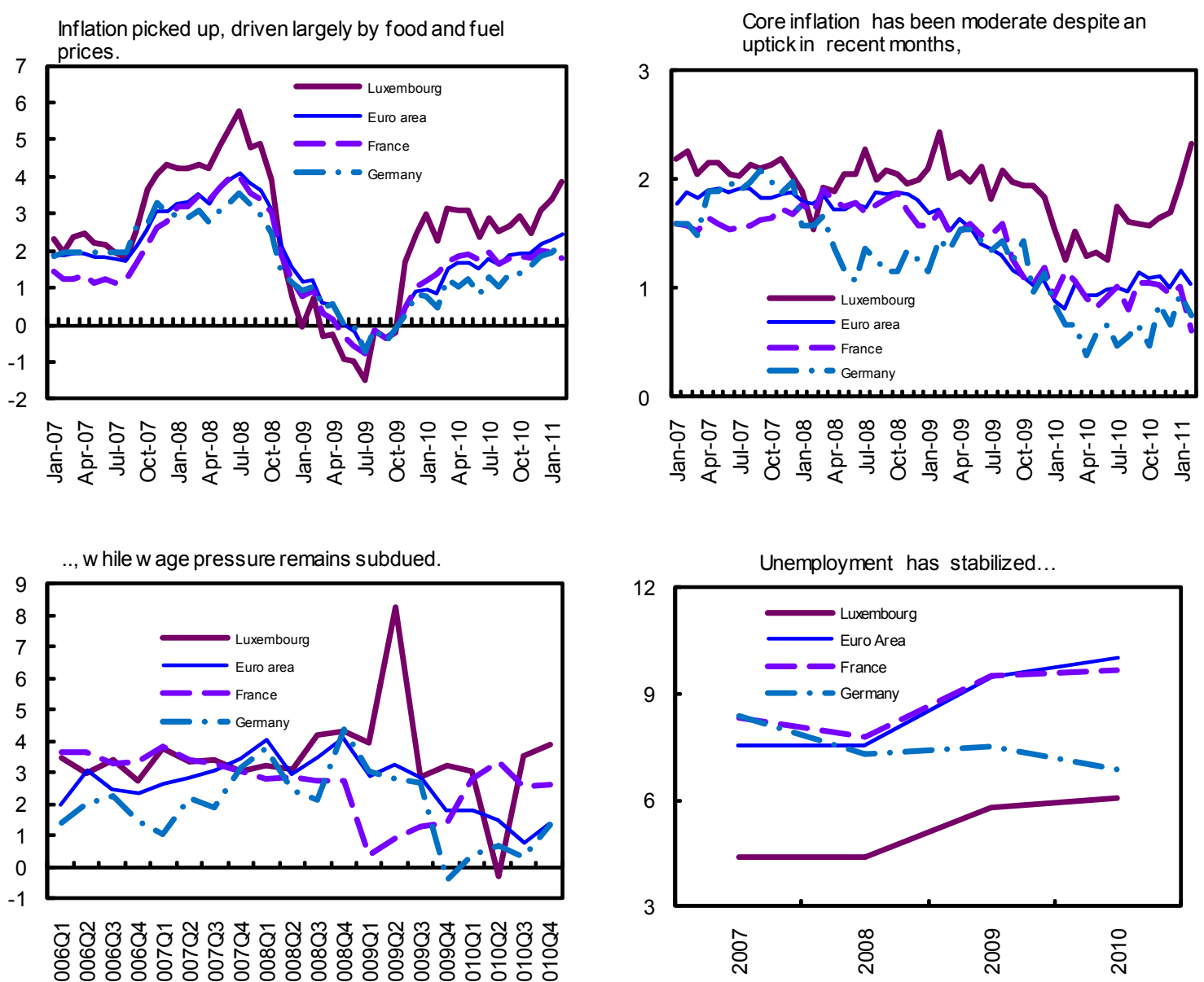

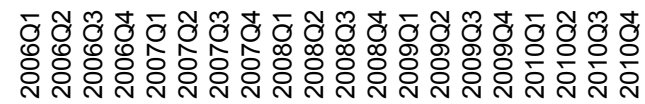

...reflecting enhanced employment support schemes.

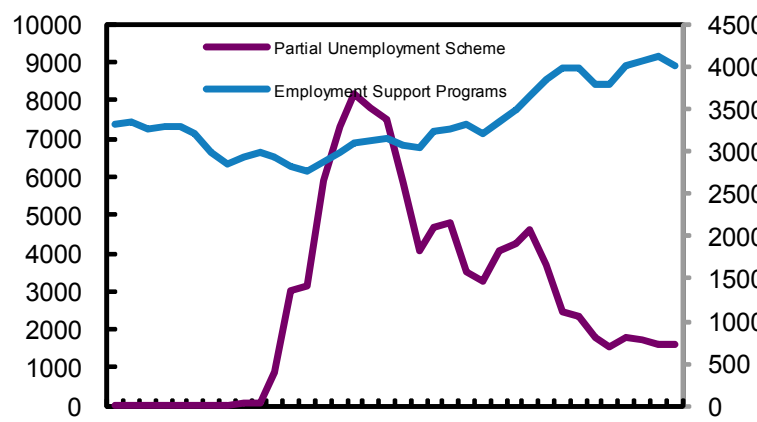

Employment grow th is gaining pace, mainly for cross border workers.

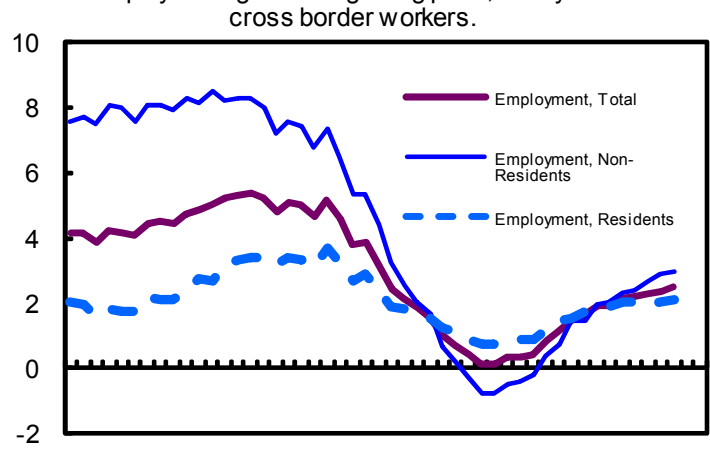

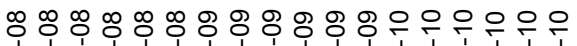

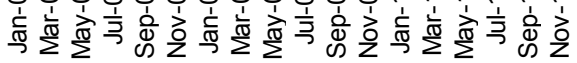

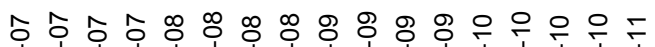

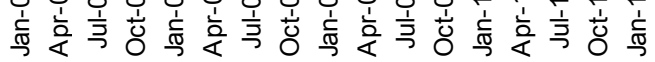

Sources: Haver; IHS Global Insight; and Luxemboug authorities. 
Figure 3. Luxembourg: Aggregate Banking Sector Assets and Funding
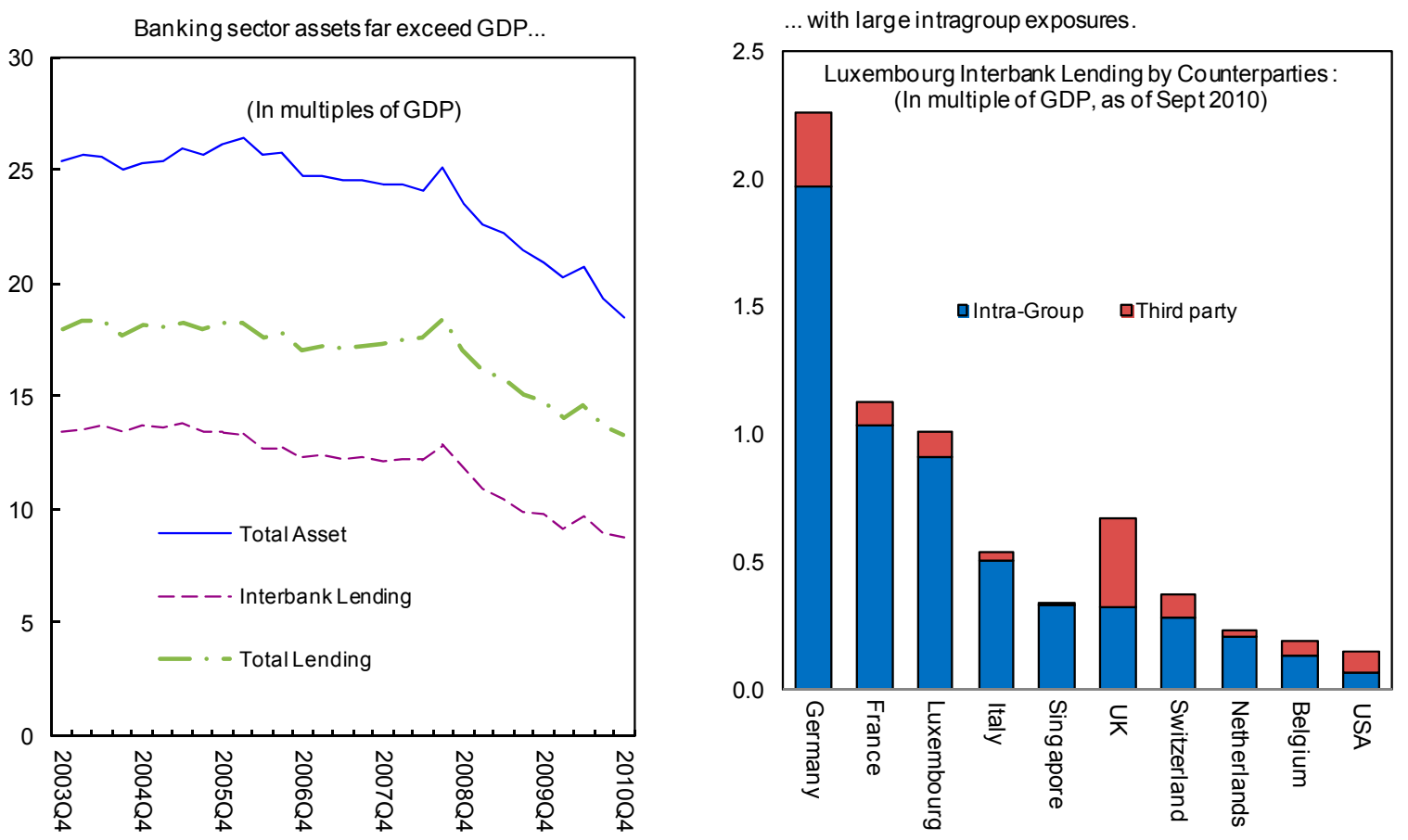

Customer and interbank deposits account for three quarters of bank liabilities...

..., but interbank deposits declined following the crisis.

(Percent of liabilities Dec 2010)
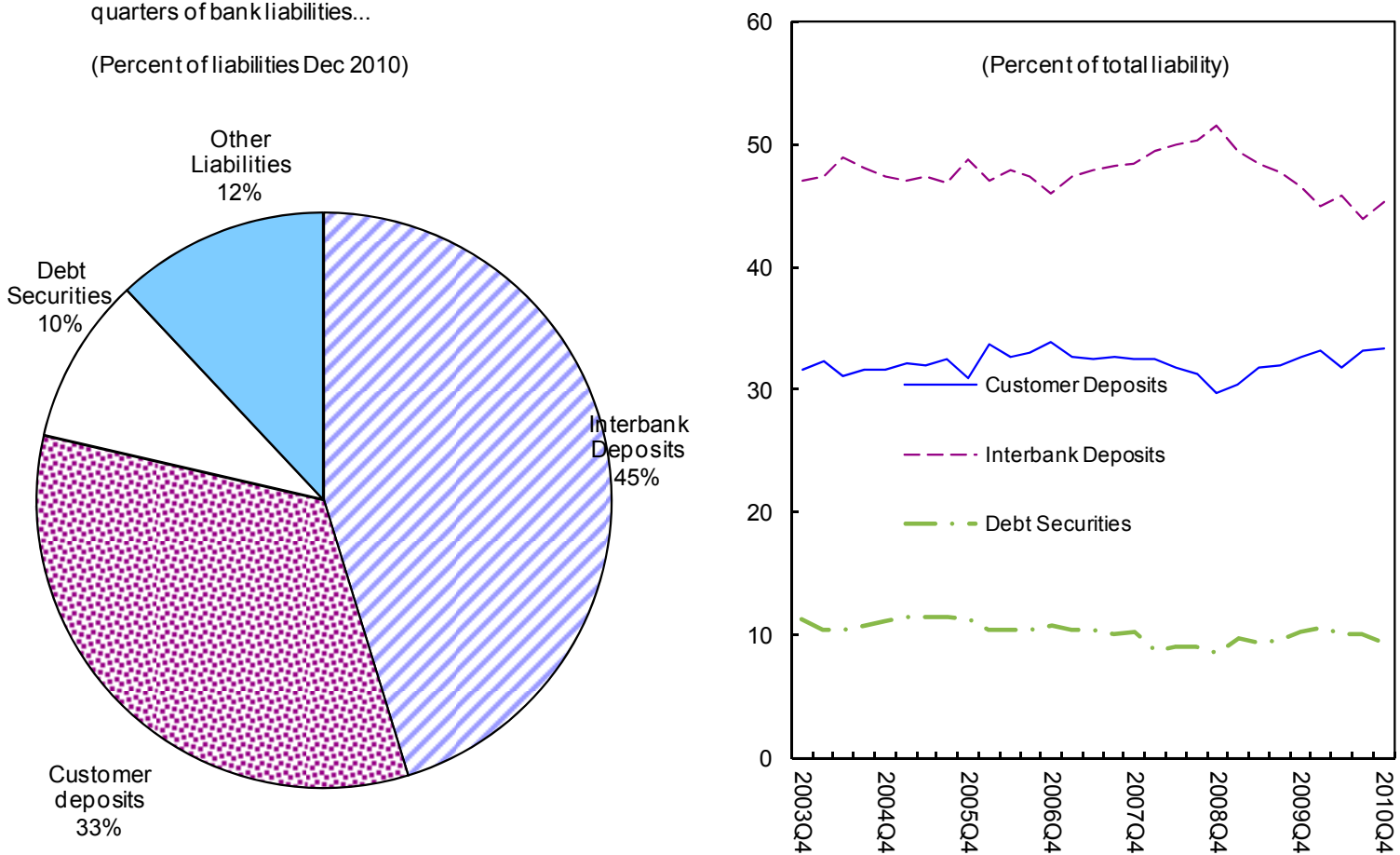

Sources: BCL, EUROSTAT, IMF staff estimates 
Figure 4. Luxembourg: Pension System Sustainability, 2007-60
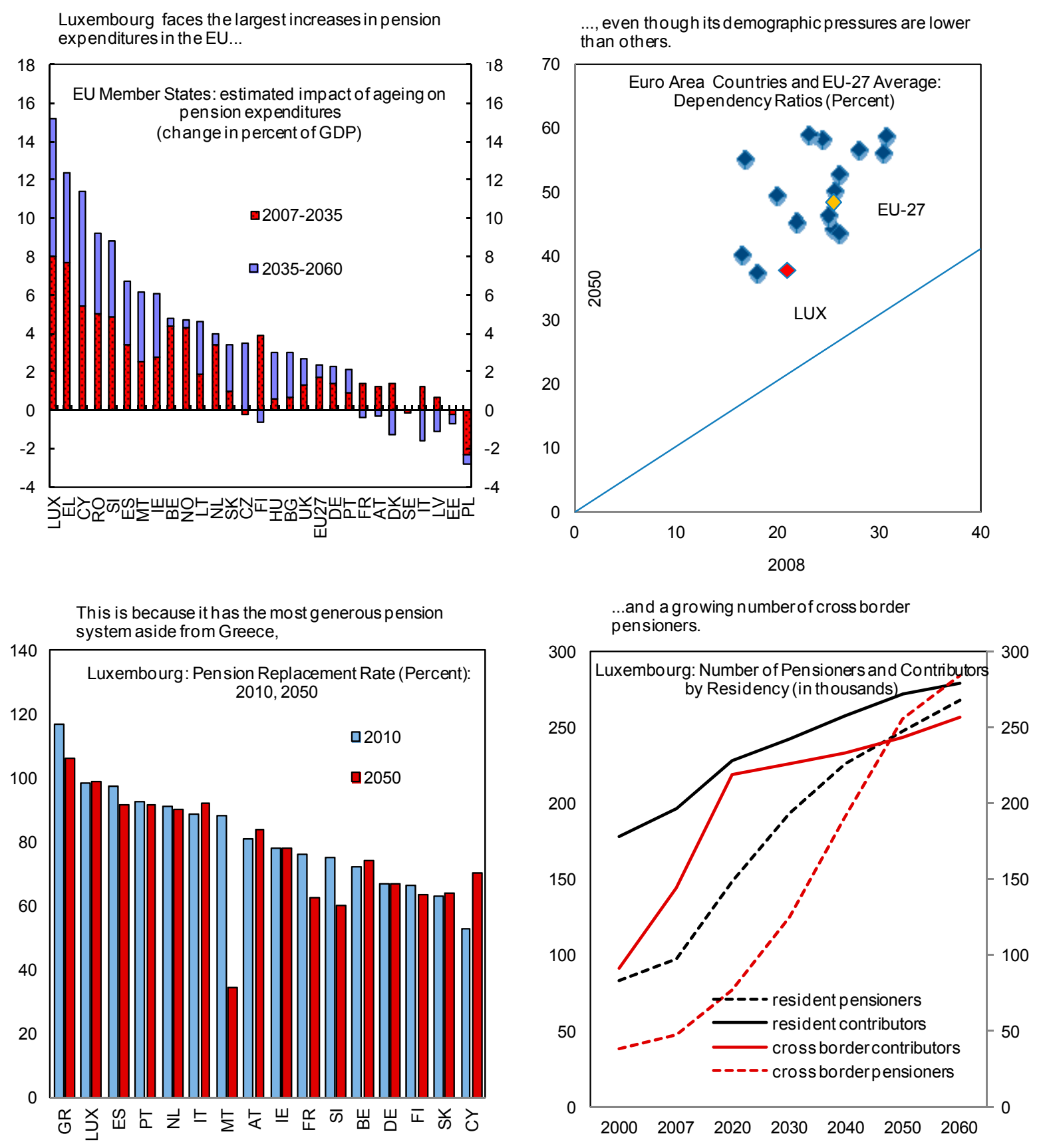

Sources: IGSS, STATEC, EUROSTAT, and OECD. 
Figure 5. Luxembourg: Fiscal Consolidation

(Percent of GDP)
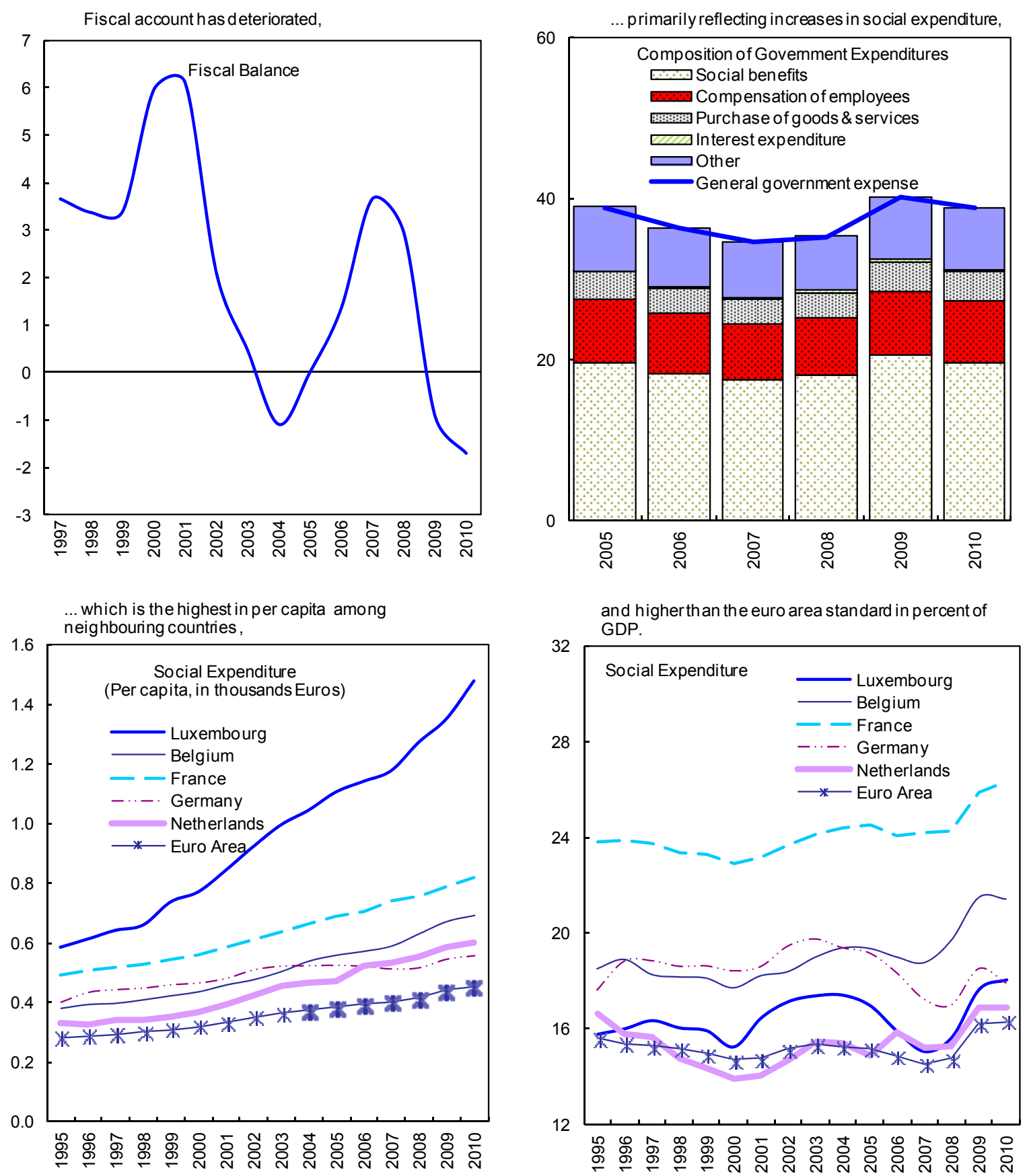

Sources:OECD; and IMF, WEO 


\section{Annex I. Labor Market Developments ${ }^{1}$}

Employment growth has picked up gradually but unevenly across sectors. Industrial workers were most severely impacted during the crisis. As economic growth has returned, employment growth started gaining pace, mainly in the construction, real estate and trade sectors. Still, employments in industry and banking sectors have remained weak in 2010. The crisis had also significantly slowed employment growth of cross border workers (Figure 2).

\section{The unemployment rate has remained high} nonetheless despite various employment support schemes. An increasing number of workers have been covered by employment support schemes. Partial unemployment compensation has also helped contain unemployment by doubling the length of time allowed to work on temporary contracts to 12 months.

\section{Moreover, long run unemployment and reclassified workers have increased, thus} highlighting the labor market's structural problems. Long-time unemployed workers suffer an erosion of their skills that, coupled with a lack of specific skills demanded by the labor markets, make finding a job exceedingly difficult. In addition, unemployment benefits have the unintended consequence of providing disincentives to work. While the external reclassification scheme has been intended to support disabled workers, its generosity could be abused by unscrupulous individuals.

\footnotetext{
${ }^{1}$ Prepared by Yuanyan Zhang
}
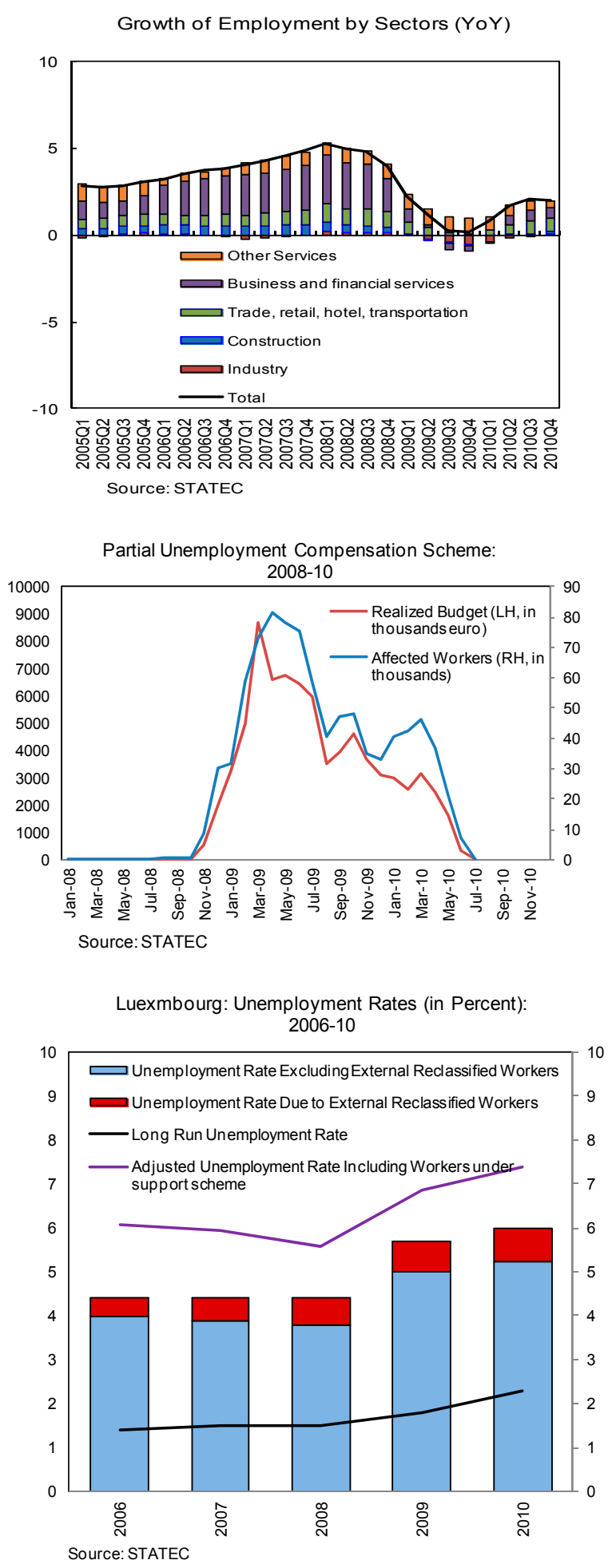


\section{Annex II. The Authorities' Supervisory Response to the Global Financial Crisis}

The crisis highlighted the risks associated with cross-border intra-group exposures with parent banks as well as flaws in governance and risk management practices of subsidiaries and related supervisory shortcomings. In these areas, the authorities' response included:

- $\quad$ Enhancing liquidity monitoring by creating a macro-financial stability unit in the BCL and revising the institutional framework for the supervision of liquidity risk, thereby entrusting the BCL with a role in market liquidity monitoring and assessing liquidity management by financial institutions. The BCL has implemented a system of daily, forward-looking liquidity reporting, and developed a battery of quantitative tools to support on- and off-site assessment of liquidity.

- $\quad$ Adding liquidity risk management regulations on qualitative aspects by formalizing the organizational structures dedicated to on-site supervision, and sharpening supervisory focus on banks' governance structures and risk management practices. These have been aimed at strengthening the role and responsibilities of local bank managers. In line with the CEBS guidelines, the CSSF introduced a more formal Supervisory Review Process, requiring banks to introduce an Internal Capital Adequacy Assessment Process (ICAAP).

- $\quad$ Stepping up supervisory scrutiny of bank leverage and sovereign risk exposures, and focusing on institutions operating in domestic retail market. As a result, capital add-ons were requested in a few banks and gradual reductions in sovereign exposures were encouraged. 


\section{Annex III: Understanding Luxembourg's Competitiveness and Its Impact on Exports ${ }^{2}$}

Luxembourg's exports are characterized by the prevalence of service exports and, despite a broadly stable overall world share, a secular decline in goods exports. This should not be surprising as it mirrors the size of the financial center relative to the economy. But it does suggest that understanding Luxembourg's export performance will require discerning between two sets of factors underlying exports.
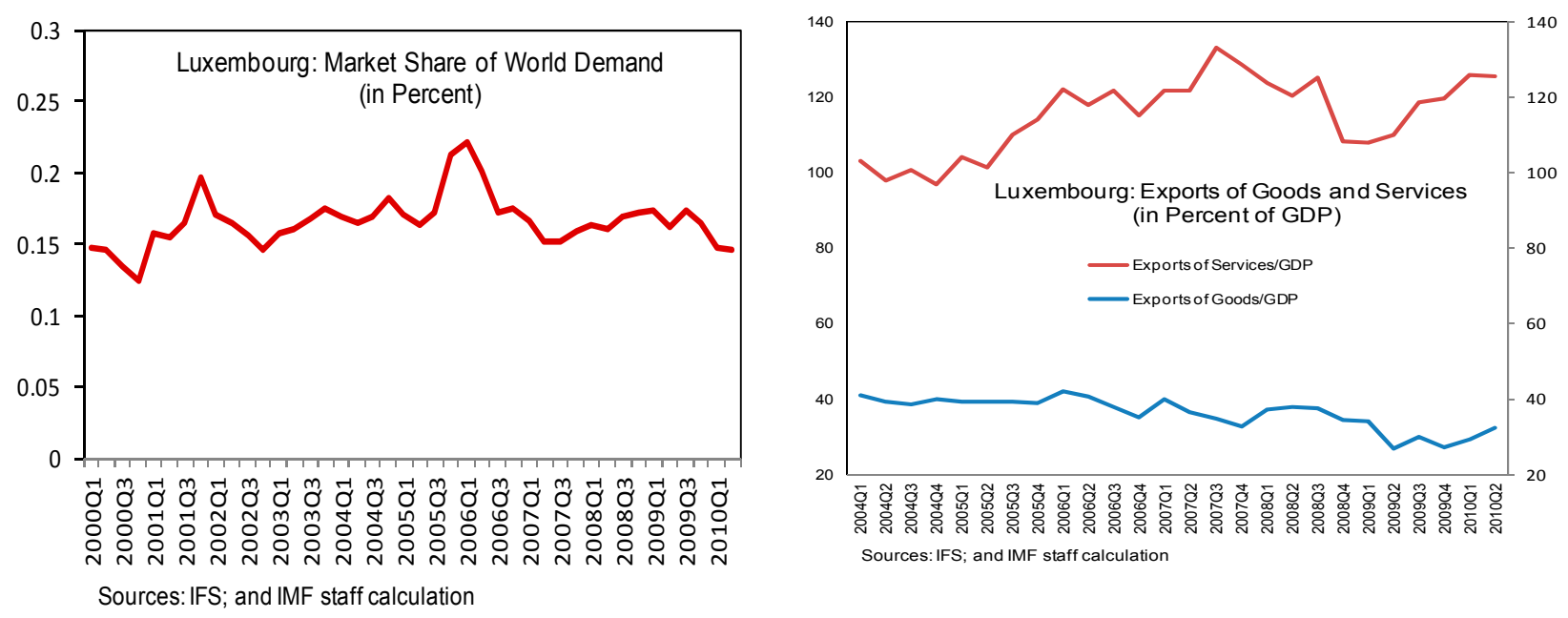

The evidence underscores the differences between service and goods exports. Specifically, in the long run

- $\quad$ The elasticity of overall exports to world demand is roughly unitary but that of service (goods) exports is about $1 / 2\left(1 \frac{1}{2}\right)$. In other words, all else equal, Luxembourg's service exports growth will tend to be outpaced by that of goods exports as the global economy recovers. Likewise, when the global economy contracted, Luxembourg's service exports were expected to be exhibit more resilience than goods exports.

- $\quad$ ULC-based real exchange rates are relevant indicators of competitiveness for both service and goods exports, in particular the measure based on manufacturing costs. In addition, service exports are sensitive to export unit cost based REER measures. In contrast, goods exports seem to be affected by CPI and WPI-based REER.

\footnotetext{
${ }^{2}$ Prepared by Yuanyan Zhang
} 
- $\quad$ The positive trend in overall exports mainly reflects a persistent increase of non-price competitiveness in service exports. Moreover, this positive trend in service exports would be consistent with financial innovation discussed in EUR's 2007 REO.

\section{Luxembourg's export developments, particularly financial services may have reflected non-}

linear effects during the crisis. The recovery of goods and service exports has benefited from the pickup of global activities, with goods exports also gain from mild competitiveness improvement. Nonetheless, service exports have been subject to volatile short term developments and potential accelerator effects stemming from the global financial turmoil; these are not explained by standard fundamental variables. Likewise, the strong recovery of service exports continues to reflect Luxembourg's favorable market power in exporting its financial services that is not fully captured by fundamentals.

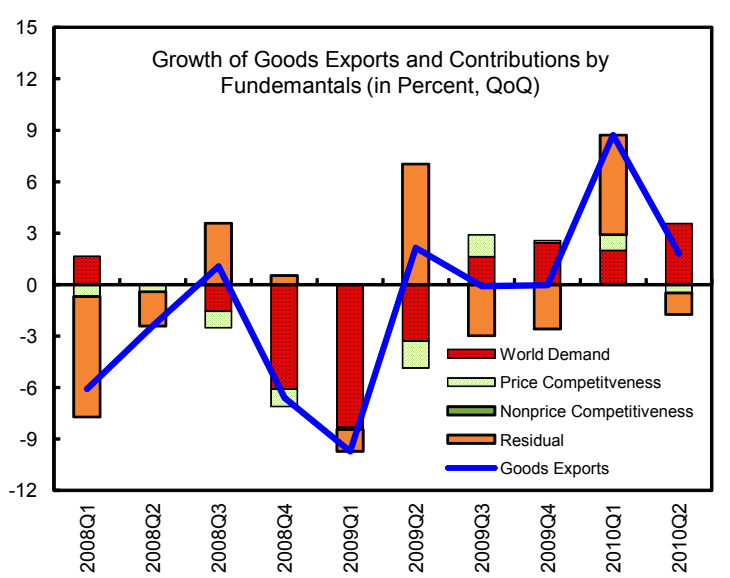

Sources: WEO, OECD, and IMF staff calculation

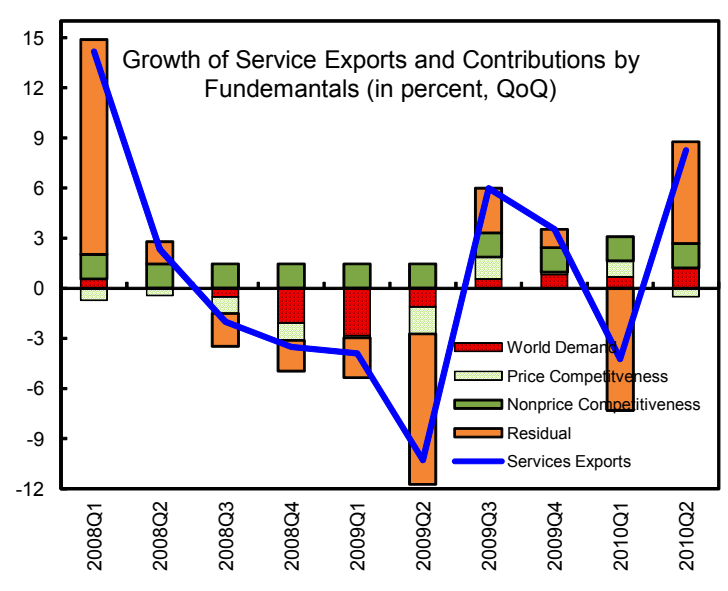

Sources: WEO, OECD, and IMF staff calculation

\section{In addition, deteriorating price competitiveness has significantly hurt Luxembourg's goods} exports while service exports have benefited from increasing non-price competitiveness. Exports of manufacturing goods would have been significantly higher had wages grown in line with the euroarea average. Assuming the same productivity growth, the lower wage increases from 2001:Q1 to 2010:Q2 would have resulted in a real exchange rate appreciation about 10 percent less than that observed. This would translate into about 7 percent higher than actual exports of goods. In contrast, the simulated and actual exports of services differ only marginally. This confirms that non-price competitiveness gain has masked the adverse effect real exchange rate appreciation (loss of price competitiveness) has had on exports of manufacturing goods. 

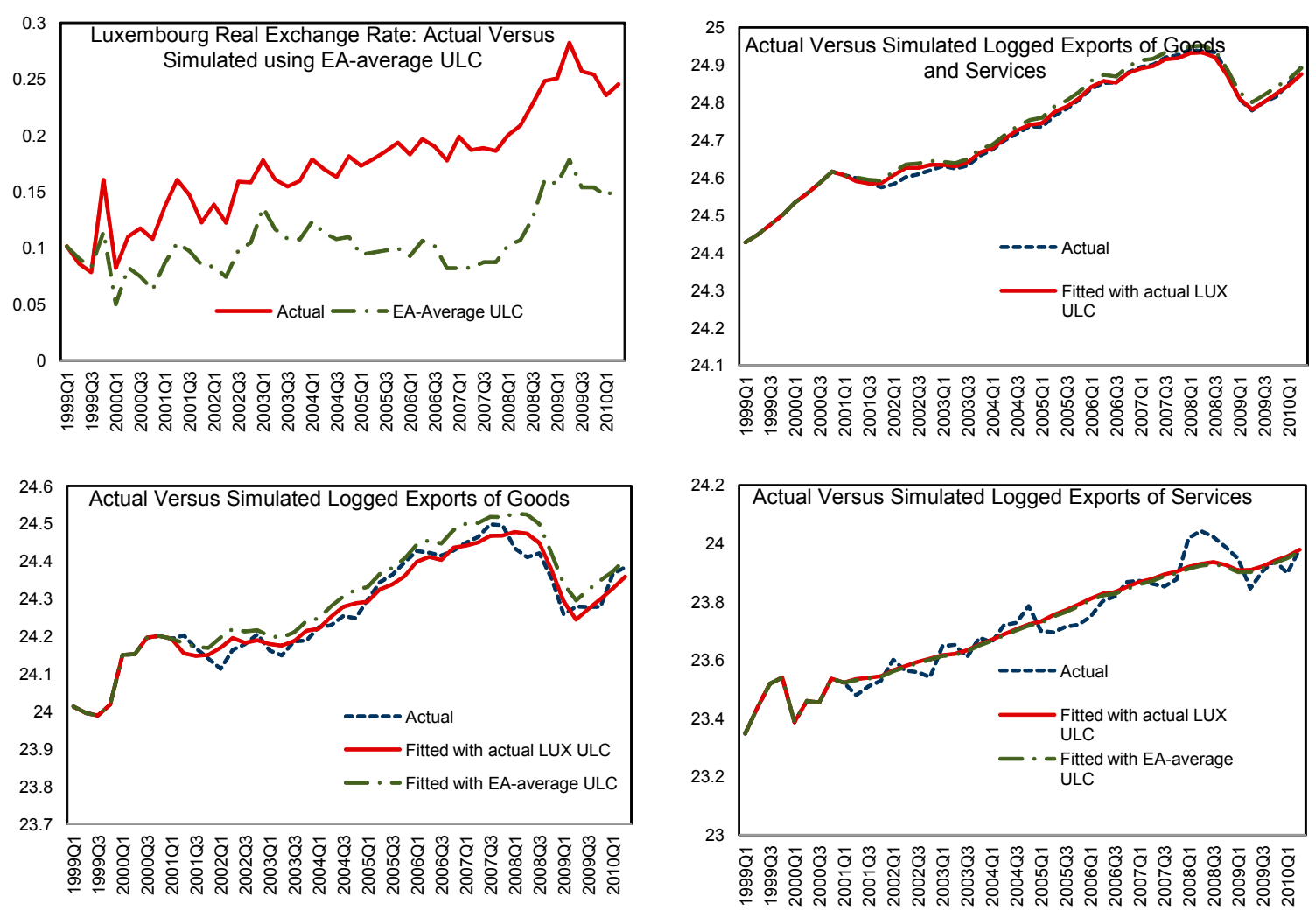

Sources: IFS; OECD; and IMF staff calculation

The empirical evidence discussed above stems from standard economic models designed to tease out long- and short-run dynamics. Specifically, export equations have been estimated using error correction models. In the long run, the specific models posit that export volume-measure either as total, service, or goods exports - depends on world demand, a trend to capture financial innovations, and a price competitiveness measure. The latter is proxied with five alternative measures, namely, unit labor cost total economy, unit labor cost manufacturing, consumer price, export unit value, and wholesale price based REERs. In the short run, the lag structures have been determined using standard lag length tests (AIC and SIC criteria). Using data from the first quarter of 1999 to the second quarter of 2010, estimation follows Engle and Granger's two-step procedure. 
Long Run Export Equations (Period of Estimation: 1999:Q1-2010:Q2)

\begin{tabular}{|c|c|c|c|c|c|}
\hline REER measures & $\begin{array}{c}\text { ULC } \\
\text { Manufacturing }\end{array}$ & $\begin{array}{c}\text { ULC } \\
\text { TotalEcon } \\
\text { omy } \\
\end{array}$ & $\mathrm{CPI}$ & WPI & $\begin{array}{c}\text { Export } \\
\text { Unit Value }\end{array}$ \\
\hline World Demand & $\begin{array}{l}0.9884 \\
(29.81)\end{array}$ & $\begin{array}{l}1.0222 \\
(30.81)\end{array}$ & $\begin{array}{l}1.0399 \\
(29.38)\end{array}$ & $\begin{array}{l}1.0501 \\
(40.83)\end{array}$ & $\begin{array}{c}1.047 \\
(38.40)\end{array}$ \\
\hline Trend & $\begin{array}{l}0.004 \\
(6.04)\end{array}$ & $\begin{array}{l}0.003 \\
(6.04)\end{array}$ & $\begin{array}{l}0.0022 \\
(3.87)\end{array}$ & $\begin{array}{l}0.0018 \\
(7.55)\end{array}$ & $\begin{array}{l}0.0014 \\
(5.18)\end{array}$ \\
\hline REER & $\begin{array}{c}-0.1463 \\
(-3.06)\end{array}$ & $\begin{array}{l}-0.1837 \\
(-1.90)\end{array}$ & $\begin{array}{l}0.0815 \\
(0.34)\end{array}$ & $\begin{array}{c}0.0999 \\
(3.02)\end{array}$ & $\begin{array}{c}0.2024 \\
(3.88)\end{array}$ \\
\hline Constant & $\begin{array}{c}20.78 \\
(167.98)\end{array}$ & $\begin{array}{l}20.6728 \\
(160.98)\end{array}$ & $\begin{array}{l}20.5768 \\
(137.86)\end{array}$ & $\begin{array}{l}20.5497 \\
(212.19)\end{array}$ & $\begin{array}{l}20.6626 \\
(222.14)\end{array}$ \\
\hline $\mathrm{R}^{\wedge} 2$ & 0.9952 & 0.9952 & 0.9961 & 0.9965 & 0.9972 \\
\hline $\begin{array}{l}\text { Phillips_perron } \\
\text { Test Statistics }\end{array}$ & 12.092 & 12.092 & 14.442 & 14.109 & 19.138 \\
\hline \multicolumn{6}{|c|}{$\begin{array}{l}\text { Note: } \\
\text { World Demand is calculated as the trading partner weighted GDP } \\
\text { Trend is used to capture the increasing export volume despite the world demand effect, e.g. } \\
\text { increasing export share of services. } \\
\text { T statistics in the parenthesis }\end{array}$} \\
\hline
\end{tabular}

Short Term Export Equations (Period of Estimation: 1999:Q1-2010:Q2)

\begin{tabular}{|c|c|c|c|c|c|}
\hline REER measures & ULC Manufacturing & $\begin{array}{c}\text { ULC } \\
\text { TotalEconomy }\end{array}$ & $\mathrm{CPI}$ & WPI & $\begin{array}{l}\text { Export Unit } \\
\text { Value }\end{array}$ \\
\hline World Demand & $\begin{array}{l}0.9821 \\
(14.13)\end{array}$ & $\begin{array}{l}1.1108 \\
(14.82)\end{array}$ & $\begin{array}{l}1.0393 \\
(14.41)\end{array}$ & $\begin{array}{l}1.1111 \\
(16.64)\end{array}$ & $\begin{array}{l}1.0839 \\
(13.41)\end{array}$ \\
\hline Lag 1 & $\begin{array}{l}0.1164 \\
(1.73)\end{array}$ & $\begin{array}{l}0.0654 \\
(0.99)\end{array}$ & $\begin{array}{l}0.1020 \\
(1.43)\end{array}$ & $\begin{array}{l}0.0510 \\
(0.66)\end{array}$ & $\begin{array}{l}0.0519 \\
(0.69)\end{array}$ \\
\hline REER & $\begin{array}{l}-0.1252 \\
(-2.36)\end{array}$ & $\begin{array}{l}-0.0467 \\
(-1.59)\end{array}$ & $\begin{array}{c}-0.2745 \\
(-1.64)\end{array}$ & $\begin{array}{l}0.0988 \\
(1.35)\end{array}$ & $\begin{array}{c}-0.0173 \\
(-0.25)\end{array}$ \\
\hline Lag 1 & $\begin{array}{c}-0.0161 \\
(-0.25)\end{array}$ & $\begin{array}{l}0.0278 \\
(0.47)\end{array}$ & $\begin{array}{c}-0.0188 \\
(-0.09)\end{array}$ & $\begin{array}{c}-0.1099 \\
(-1.63)\end{array}$ & $\begin{array}{c}-0.0342 \\
(-0.40)\end{array}$ \\
\hline $\operatorname{Lag} 2$ & $\begin{array}{l}0.0560 \\
(1.01)\end{array}$ & $\begin{array}{l}0.0032 \\
(0.05)\end{array}$ & $\begin{array}{l}0.2076 \\
(0.94)\end{array}$ & $\begin{array}{l}0.0592 \\
(0.96)\end{array}$ & $\begin{array}{l}0.0034 \\
(0.04)\end{array}$ \\
\hline Lagged CV & $\begin{array}{l}-0.2385 \\
(-2.12)\end{array}$ & $\begin{array}{l}-0.1914 \\
(-1.63)\end{array}$ & $\begin{array}{l}-0.2395 \\
(-1.96)\end{array}$ & $\begin{array}{l}-0.2197 \\
(-1.53)\end{array}$ & $\begin{array}{l}-0.3036 \\
(-1.98)\end{array}$ \\
\hline Constant & $\begin{array}{l}0.0025 \\
(2.20)\end{array}$ & $\begin{array}{l}0.0016 \\
(1.32)\end{array}$ & $\begin{array}{l}0.002 \\
(1.45)\end{array}$ & $\begin{array}{l}0.0015 \\
(1.43)\end{array}$ & $\begin{array}{l}0.002 \\
(2.02)\end{array}$ \\
\hline$R^{\wedge} 2$ & 0.946 & 0.943 & 0.9334 & 0.9295 & 0.9409 \\
\hline
\end{tabular}




\begin{tabular}{|c|c|c|c|c|c|}
\hline \multicolumn{6}{|c|}{ Long Run Export Equation (Goods, Period of Estimation: 1999:Q1-2010:Q2) } \\
\hline REER measures & $\begin{array}{c}\text { ULC } \\
\text { Manufacturing }\end{array}$ & $\begin{array}{c}\text { ULC } \\
\text { TotalEconomy }\end{array}$ & $\mathrm{CPI}$ & WPI & $\begin{array}{c}\text { Export } \\
\text { Unit Value }\end{array}$ \\
\hline World demand & $\begin{array}{l}1.4607 \\
(14.39)\end{array}$ & $\begin{array}{l}1.3804 \\
(12.45)\end{array}$ & $\begin{array}{l}1.3879 \\
(15.55)\end{array}$ & $\begin{array}{l}1.4458 \\
(14.14)\end{array}$ & $\begin{array}{l}1.2674 \\
(14.49)\end{array}$ \\
\hline Trend & $\begin{array}{c}-0.0036 \\
(-1.21)\end{array}$ & $\begin{array}{c}-0.0016 \\
(-0.88)\end{array}$ & $\begin{array}{c}-0.0008 \\
(-0.44)\end{array}$ & $\begin{array}{l}-0.002 \\
(-1.17)\end{array}$ & $\begin{array}{c}-0.0028 \\
(-0.99)\end{array}$ \\
\hline REER & $\begin{array}{c}-0.1194 \\
(-1.70)\end{array}$ & $\begin{array}{c}-0.1978 \\
(-1.65)\end{array}$ & $\begin{array}{c}-0.7582 \\
(-1.82)\end{array}$ & $\begin{array}{c}-0.0831 \\
(-1.55)\end{array}$ & $\begin{array}{c}0.0293 \\
(0.28)\end{array}$ \\
\hline Constant & $\begin{array}{c}18.60 \\
(48.37)\end{array}$ & $\begin{array}{c}18.92 \\
(43.00)\end{array}$ & $\begin{array}{c}19.2653 \\
(4.86)\end{array}$ & $\begin{array}{c}18.65 \\
(48.10)\end{array}$ & $\begin{array}{c}19.30 \\
(59.22)\end{array}$ \\
\hline $\mathrm{R}^{\wedge} 2$ & 0.9425 & 0.9418 & 0.9527 & 0.9418 & 0.9567 \\
\hline $\begin{array}{l}\text { Phillips_perron } \\
\text { Test statistics }\end{array}$ & -23.837 & -25.784 & -23.954 & -26.126 & -20.151 \\
\hline \multicolumn{6}{|c|}{$\begin{array}{l}\text { Note: } \\
\text { World Demand is calculated as the trading partner weighted Imports from Luxembourg } \\
\text { Trend is used to capture the increasing export volume despite the world demand effect, e.g. } \\
\text { increasing export share of services. } \\
\text { T statistics in the parenthesis }\end{array}$} \\
\hline
\end{tabular}

\begin{tabular}{|c|c|c|c|c|c|}
\hline \multicolumn{6}{|c|}{ Short Term Export Equations (Goods, Period of Estimation: 1999:Q1-2010:Q2) } \\
\hline REER measures & ULC Manufacturing & $\begin{array}{c}\text { ULC } \\
\text { TotalEconomy }\end{array}$ & $\mathrm{CPI}$ & WPI & $\begin{array}{l}\text { Export Unit } \\
\text { Value }\end{array}$ \\
\hline World Demand & $\begin{array}{l}1.2344 \\
(3.92)\end{array}$ & $\begin{array}{l}1.4068 \\
(4.04)\end{array}$ & $\begin{array}{l}1.3275 \\
(3.92)\end{array}$ & $\begin{array}{l}1.2305 \\
(4.30)\end{array}$ & $\begin{array}{l}1.2376 \\
(3.32)\end{array}$ \\
\hline Lag 1 & $\begin{array}{l}0.2468 \\
(0.83)\end{array}$ & $\begin{array}{l}-0.0365 \\
(-0.12)\end{array}$ & $\begin{array}{c}0.0606 \\
(0.19)\end{array}$ & $\begin{array}{c}0.4700 \\
(1.49)\end{array}$ & $\begin{array}{l}0.0621 \\
(0.19)\end{array}$ \\
\hline REER & $\begin{array}{c}-0.5759 \\
(-2.23)\end{array}$ & $\begin{array}{c}-0.1829 \\
(-2.12)\end{array}$ & $\begin{array}{c}-1.3319 \\
(-1.60)\end{array}$ & $\begin{array}{c}-0.8229 \\
(-2.80)\end{array}$ & $\begin{array}{l}0.3377 \\
(1.07)\end{array}$ \\
\hline Lag 1 & $\begin{array}{l}0.6057 \\
(2.23)\end{array}$ & $\begin{array}{l}0.1929 \\
(0.56)\end{array}$ & $\begin{array}{l}0.3181 \\
(0.35)\end{array}$ & $\begin{array}{r}0.2727 \\
(0.94)\end{array}$ & $\begin{array}{l}0.0398 \\
(0.11)\end{array}$ \\
\hline Lag 2 & $\begin{array}{l}-0.2715 \\
(-1.09)\end{array}$ & $\begin{array}{l}-0.2001 \\
(-0.64)\end{array}$ & $\begin{array}{l}-0.382 \\
(-0.39)\end{array}$ & $\begin{array}{c}-0.1422 \\
(-0.57)\end{array}$ & $\begin{array}{l}0.0908 \\
(0.27)\end{array}$ \\
\hline Lagged CV & $\begin{array}{l}-0.5723 \\
(-3.53)\end{array}$ & $\begin{array}{c}-0.5066 \\
(-2.91)\end{array}$ & $\begin{array}{c}-0.5259 \\
(-3.03)\end{array}$ & $\begin{array}{c}-0.5542 \\
(-3.36)\end{array}$ & $\begin{array}{c}-0.6736 \\
(-3.45)\end{array}$ \\
\hline Constant & $\begin{array}{l}-0.0028 \\
(-0.54)\end{array}$ & $\begin{array}{l}-0.002 \\
(-0.36)\end{array}$ & $\begin{array}{r}-0.0004 \\
(-0.07)\end{array}$ & $\begin{array}{c}-0.0012 \\
(-0.28)\end{array}$ & $\begin{array}{l}-0.0042 \\
(-0.93)\end{array}$ \\
\hline $\mathrm{R}^{\wedge} 2$ & 0.5634 & 0.5583 & 0.5387 & 0.6274 & 0.5582 \\
\hline $\begin{array}{l}\text { Note: All variabl } \\
\text { REERs in each }\end{array}$ & $\begin{array}{l}\text { term are in log dif } \\
\text { different, based }\end{array}$ & $\begin{array}{l}\text { nces } \\
\text { he specified }\end{array}$ & ures & & \\
\hline
\end{tabular}




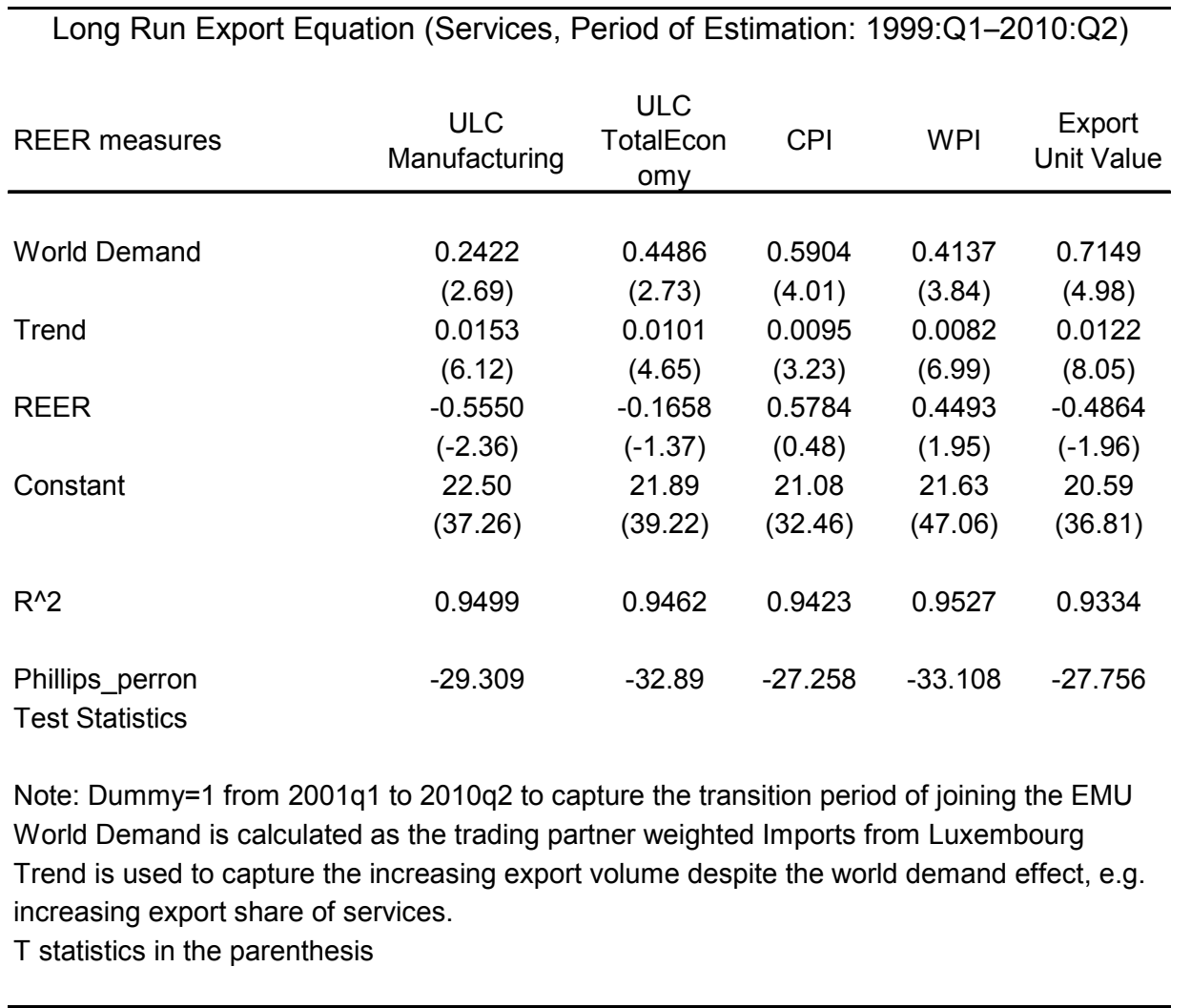

\begin{tabular}{|c|c|c|c|c|c|}
\hline \multicolumn{6}{|c|}{ Short Term Export Equations (Services,Period of Estimation: 1999:Q1-2010:Q2) } \\
\hline REER measures & ULC Manufacturing & $\begin{array}{c}\text { ULC } \\
\text { TotalEconomy }\end{array}$ & $\mathrm{CPI}$ & WPI & $\begin{array}{l}\text { Export Unit } \\
\text { Value }\end{array}$ \\
\hline World Demand & $\begin{array}{c}0.4414 \\
(0.88)\end{array}$ & $\begin{array}{c}0.5474 \\
(0.92)\end{array}$ & $\begin{array}{c}0.5484 \\
(0.94)\end{array}$ & $\begin{array}{c}0.9368 \\
(2.12)\end{array}$ & $\begin{array}{l}0.9627 \\
(1.57)\end{array}$ \\
\hline Lag 1 & $\begin{array}{l}0.0856 \\
(0.19)\end{array}$ & $\begin{array}{l}0.2511 \\
(0.52)\end{array}$ & $\begin{array}{l}0.1571 \\
(0.30)\end{array}$ & $\begin{array}{c}-0.6393 \\
(-1.33)\end{array}$ & $\begin{array}{l}0.0280 \\
(0.05)\end{array}$ \\
\hline REER & $\begin{array}{l}0.5503 \\
(1.52)\end{array}$ & $\begin{array}{l}0.1075 \\
(0.22)\end{array}$ & $\begin{array}{l}1.149 \\
(0.84)\end{array}$ & $\begin{array}{l}1.6998 \\
(3.75)\end{array}$ & $\begin{array}{c}-0.5253 \\
(-1.03)\end{array}$ \\
\hline $\operatorname{Lag} 1$ & $\begin{array}{c}-1.0849 \\
(-2.39)\end{array}$ & $\begin{array}{c}-0.1451 \\
(-0.26)\end{array}$ & $\begin{array}{l}-0.702 \\
(-0.48)\end{array}$ & $\begin{array}{c}-0.7601 \\
(-1.72)\end{array}$ & $\begin{array}{c}-0.2703 \\
(-0.46)\end{array}$ \\
\hline Lag 2 & $\begin{array}{l}0.5487 \\
(1.69)\end{array}$ & $\begin{array}{l}0.1028 \\
(0.92)\end{array}$ & $\begin{array}{c}0.4769 \\
(0.73)\end{array}$ & $\begin{array}{c}0.3855 \\
(1.01)\end{array}$ & $\begin{array}{c}(-0.3231) \\
(-0.59)\end{array}$ \\
\hline Lagged CV & $\begin{array}{c}-0.6323 \\
(-3.68)\end{array}$ & $\begin{array}{c}-0.4889 \\
(-2.72)\end{array}$ & $\begin{array}{c}-0.5193 \\
(-3.34)\end{array}$ & $\begin{array}{l}-0.541 \\
(-3.23)\end{array}$ & $\begin{array}{c}-0.5504 \\
(-3.02)\end{array}$ \\
\hline Constant & $\begin{array}{l}0.0115 \\
(1.44)\end{array}$ & $\begin{array}{l}0.0075 \\
(0.82)\end{array}$ & $\begin{array}{l}0.0081 \\
(0.92)\end{array}$ & $\begin{array}{l}0.0053 \\
(0.81)\end{array}$ & $\begin{array}{l}0.0131 \\
(1.74)\end{array}$ \\
\hline $\mathrm{R}^{\wedge} 2$ & 0.5601 & 0.4367 & 0.3377 & 0.5549 & 0.4356 \\
\hline
\end{tabular}


INTERNATIONAL MONETARY FUND

LUXEMBOURG

Staff Report for the 2011 Article IV Consultation-Informational Annex

Prepared by European Department

April 27, 2011

Contents

Page

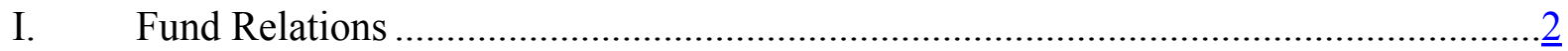

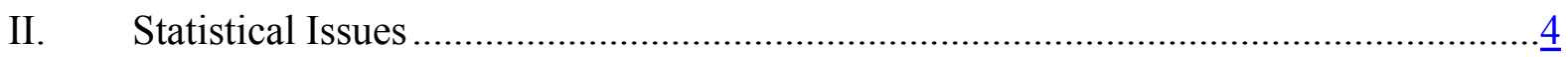

CInternational Monetary Fund. Not for Redistribution 
ANNEX I. LuXEMbourg: Fund RELATIONS

(As of April 5, 2011)

- Mission: March 24, April 4, 2011. The concluding statement of the mission is available at http://www.imf.org/external/np/ms/2011/040411.htm.

- Staff team: Messrs. Hoffmaister (Head), Vázquez and Ms. Zhang (all EUR), and Mr. Blancher (MCM).

- Country interlocutors included: Mr. Luc Frieden, Minister of Finance; Mr. Yves Mersch, Central Bank Governor; Mr. Mars di Bartolomeo, Minister of Social Security; Mr. Nicolas Schmit, Minister of Labor; and Mr. Jean Guill, General Director, Financial Sector Supervisory Commission. Mr. Dirk Mevis, IMF Advisor to the Executive Director attended the discussions. Mr. Johann Prader, Alternate Executive Director, joined the concluding meeting. Outreach activities included meetings with trade unions and a press conference.

- $\quad$ Fund relations: The previous Article IV consultation took place on April 7-19, 2010 (IMF Country Report No. 10/161). The staff report and associated Executive Board's assessment are available at:

http://www.imf.org/external/pubs/cat/longres.aspx?sk=23926.0.

- Data: Luxembourg subscribes to the Fund's Special Data Dissemination Standard, and data provision is adequate for surveillance (Annex II).

I. Membership Status: Joined: December 27, 1945; Article VIII

II. General Resources Account:

Quota

Fund Holdings of Currency

Reserve position in Fund

SDR Million

279.10

199.80

79.32

SDR Million

246.62

243.39
Percent Quota

100.00

71.59

28.42

Percent Allocation

100.00

98.69

IV. Outstanding Purchases and Loans: None

V. Financial Arrangements: None 
VI. Projected Payments to the Fund (SDR million; based on existing use of resources and present holdings of SDRs):

\begin{tabular}{lrrrrr} 
& \multicolumn{5}{c}{ Forthcoming } \\
\cline { 2 - 6 } & $\mathbf{2 0 1 1}$ & $\mathbf{2 0 1 2}$ & $\mathbf{2 0 1 3}$ & $\mathbf{2 0 1 4}$ & $\mathbf{2 0 1 5}$ \\
Principal & 0.00 & 0.00 & 0.00 & 0.00 & 0.00 \\
Charges/Interest & $\underline{0.01}$ & $\underline{0.02}$ & $\underline{0.02}$ & $\underline{0.02}$ & $\underline{0.02}$ \\
Total & 0.01 & 0.02 & 0.02 & 0.02 & 0.02
\end{tabular}

VII. Exchange Rate Arrangement:

Luxembourg's currency is the euro, which floats freely and independently against other currencies. Luxembourg has accepted the obligations of Article VIII, Sections 2, 3, and 4, and maintains an exchange system free of restrictions on payments and transfers for current international transactions, other than restrictions notified to the Fund under Decision No. $144(52 / 51)$.

\section{Anti-Money Laundering/Combating the Financing of Terrorism (AML/CFT):}

The Financial Action Task Force (FATF) recently concluded that Luxembourg has largely addressed the major shortcomings identified in its AML/CFT framework. In its February 2010 mutual evaluation report on Luxembourg, the FATF identified numerous shortcomings, judging that overall Luxembourg's AML/CFT efforts were not proportional to the risks associated with its role as a key international financial center. As a result, Luxembourg was placed under enhanced scrutiny by the FATF's International Cooperation Review Group (ICRG). Since then, the authorities implemented a speedy remedial action plan, including the adoption of AML/CFT legislation addressing deficiencies in financial and nonfinancial sector areas, and increased supervisory actions in the financial sector. At its latest plenary meeting, the FATF noted that authorities have responded rapidly and agreed to remove Luxembourg from the ICRG process, although the effectiveness of these newly implemented measures has not yet been ascertained. Luxembourg will continue to provide updates on its progress as part of the regular FATF follow-up process for assessed members. 
ANNEX II. LUXEMBOURG: STATISTICAL ISSUES

(As of April 5, 2011)

\section{Assessment of Data Adequacy for Surveillance}

General: Data provision is adequate for surveillance. The Central Service for Statistics and Economic Studies (Statec) regularly publishes a full range of economic and financial data and provides an advance release calendar for main statistical releases at: http://www.statistiques.public.lu/fr/agenda/calendrier-diffusion/index.html.

On-line access to Statec's databases and those of other jurisdictions is available to all users simultaneously at the time of release through the Statistics Portal of Luxembourg.

Key publicly accessible websites for macroeconomic data and analysis are:

Statistics Portal of Luxembourg http://www.statistiques.public.lu/fr/

Statec .http://www.statec.public.lu/fr/index.html

Central Bank of Luxembourg ..http://www.bcl.lu/en/index.php

Ministry of Finance .http://www.mf.public.lu/

National Accounts: Luxembourg avails itself of the SDDS special flexibility for the timeliness of the national accounts, and generally disseminates national accounts data not later than four months after the reference period (the SDDS timeliness requirement for the national accounts is three months). Reduction of the reporting lag would aid surveillance.

\section{Data Standards and Quality}

Subscriber to the Fund's Special Data No data ROSC is available.

Dissemination Standard (SDDS) since May 12,2006 . Uses SDDS flexibility options on the timeliness of national accounts and analytical accounts of the central bank. 
LUXEMBOURG: TABLE OF COMMON INDICATORS REQUIRED FOR SURVEILLANCE (As of April 5, 2011)

\begin{tabular}{|c|c|c|c|c|c|}
\hline & $\begin{array}{c}\text { Date of } \\
\text { Latest } \\
\text { Observation }\end{array}$ & $\begin{array}{c}\text { Date } \\
\text { Received }\end{array}$ & $\begin{array}{c}\text { Frequency } \\
\text { of } \\
\text { Data }^{7}\end{array}$ & $\begin{array}{l}\text { Frequency } \\
\text { of } \\
\text { Reporting }^{7}\end{array}$ & $\begin{array}{l}\text { Frequency } \\
\text { of } \\
\text { Publication }^{7}\end{array}$ \\
\hline Exchange Rates & $04 / 05 / 11$ & $04 / 05 / 11$ & $\mathrm{D}$ & $\mathrm{D}$ & $\mathrm{D}$ \\
\hline $\begin{array}{l}\text { International Reserve Assets and } \\
\text { Reserve Liabilities of the Monetary } \\
\text { Authorities }^{1}\end{array}$ & $02 / 11 / 11$ & $03 / 30 / 11$ & M & M & M \\
\hline Reserve/Base Money & $02 / 11 / 11$ & $03 / 30 / 11$ & M & M & M \\
\hline Broad Money & $02 / 11 / 11$ & $03 / 30 / 11$ & M & M & M \\
\hline Central Bank Balance Sheet & $02 / 11 / 11$ & $03 / 30 / 11$ & M & M & M \\
\hline $\begin{array}{l}\text { Consolidated Balance Sheet of the } \\
\text { Banking System }\end{array}$ & $02 / 11 / 11$ & $03 / 30 / 11$ & M & M & M \\
\hline Interest Rates $^{2}$ & $04 / 05 / 11$ & $04 / 05 / 11$ & $\mathrm{D}$ & $\mathrm{D}$ & $\mathrm{D}$ \\
\hline Consumer Price Index & $02 / 11 / 11$ & $03 / 09 / 11$ & M & M & M \\
\hline $\begin{array}{l}\text { Revenue, Expenditure, Balance and } \\
\text { Composition of Financing }{ }^{3}-\text { General } \\
\text { Government }^{4}\end{array}$ & 2010 Q4 & $04 / 05 / 11$ & Q & Q & $\mathrm{Q}$ \\
\hline $\begin{array}{l}\text { Revenue, Expenditure, Balance and } \\
\text { Composition of Financing }{ }^{3}-\text { Central } \\
\text { Government }\end{array}$ & 2010 Q4 & $04 / 05 / 11$ & Q & $\mathrm{Q}$ & $\mathrm{Q}$ \\
\hline $\begin{array}{l}\text { Stocks of Central Government and } \\
\text { Central Government-Guaranteed Debt }\end{array}$ & $02 / 11 / 11$ & $04 / 05 / 11$ & Q & Q & Q \\
\hline External Current Account Balance & 2010 Q4 & $03 / 30 / 11$ & Q & Q & Q \\
\hline $\begin{array}{l}\text { Exports and Imports of Goods and } \\
\text { Services }\end{array}$ & $01 / 11 / 11$ & $03 / 28 / 11$ & M & M & M \\
\hline GDP/GNP & 2010 Q4 & $04 / 12 / 11$ & Q & Q & Q \\
\hline Gross External Debt & $03 / 11 / 11$ & $04 / 05 / 11$ & Q & Q & Q \\
\hline International Investment Position ${ }^{6}$ & 2010 Q4 & $03 / 30 / 11$ & Q & Q & Q \\
\hline
\end{tabular}

${ }^{1}$ Including reserve assets that are pledged or otherwise encumbered.

${ }^{2}$ Both market-based and officially-determined, including discount rates, money market rates, rates on treasury bills, notes and bonds.

${ }^{3}$ Foreign, domestic bank, and domestic nonbank financing.

${ }^{4}$ The general government consists of the central government (budgetary funds, extra budgetary funds, and social security funds) and state and local governments.

${ }^{5}$ Including currency and maturity composition.

${ }^{6}$ Includes external gross financial asset and liability positions vis-à-vis nonresidents.

${ }^{7}$ Daily (D); weekly (W); monthly (M); quarterly (Q); annually (A); irregular (I); and not available (NA). 


\section{IMF Executive Board Concludes 2011 Article IV Consultation with Luxembourg}

On May 13, 2010, the Executive Board of the International Monetary Fund (IMF) concluded the Article IV consultation with Luxembourg. ${ }^{1}$

\section{Background}

Luxembourg's economy has begun its recovery. Mirroring developments in other advanced European countries, Luxembourg experienced stronger-than-expected growth in 2010. Besides fiscal stimulus, economic activity was initially underpinned by investment and restocking. But exports have increased markedly since the second quarter of 2010 , notably financial services and metal products. Private consumption has also begun to gradually recover despite moderate increases in consumer lending spreads. Employment growth has been gaining pace but, despite enhanced employment support programs, the unemployment rate has not eased. Weak wage growth has tempered core inflation even though headline inflation has been boosted by global commodity price developments and administered price increases.

The financial sector has stabilized. The investment fund industry has experienced a fast recovery with total assets surpassing their pre-crisis peak, reflecting strong investor demand as well as market valuation gains. In the banking sector, there were no further failures after the peak of the crisis and restructuring has continued, including in the context of EU-approved

\footnotetext{
${ }^{1}$ Under Article IV of the IMF's Articles of Agreement, the IMF holds bilateral discussions with members, usually every year. A staff team visits the country, collects economic and financial information, and discusses with officials the country's economic developments and policies. On return to headquarters, the staff prepares a report, which forms the basis for discussion by the Executive Board. At the conclusion of the discussion, the Managing Director, as Chairman of the Board, summarizes the views of Executive Directors, and this summary is transmitted to the country's authorities. An explanation of any qualifiers used in summings up can be found here: http://www.imf.org/external/np/sec/misc/qualifiers.htm.
} 
reorganization plans. Overall bank capitalization has increased and appears broadly adequate, but remains uneven across banks. Aggregate bank balance sheets have continued to shrink through early 2011 . While interest margins have declined, bank profits have increased due to commission and fee income and lower provisioning needs.

The Financial Sector Assessment Program (FSAP) identified the main financial risks as liquidity and credit risks related to intra-group exposures and sovereign bond holdings. Luxembourgbased banks generate structural excess liquidity from their operations, which is channeled to parent banks abroad. These intra-group activities, given their size and concentration, entail liquidity and solvency risks for Luxembourg-based banks. In addition, some institutions maintain large direct exposures to sovereign risk from the EU periphery. Stress tests suggest that in a scenario of protracted slow growth in core Europe and renewed deterioration in market perceptions of sovereign risk, banks would also face indirect risks originating from exposures of their parent banking groups, particularly those incorporated in the distressed countries.

Growth is projected to slow from about 31/2 percent in 2010 to about 31/4 percent in 2011 in line with prospects in core Europe. Inflation is projected to increase in 2011 reflecting global food and fuel price developments. But price pressures will likely remain subdued given slack in the economy and delays in automatic wage indexation increases.

\section{Executive Board Assessment}

Executive Directors welcomed the continued strengthening of Luxembourg's recovery and the authorities' supportive fiscal policy in 2010 as well as their role in stabilizing the financial sector. Looking ahead, Directors concurred that the key challenges are to address remaining financial sector vulnerabilities, maintain a sustainable fiscal position, and bolster competitiveness and employment creation.

Directors welcomed the FSAP update, and commended the authorities' intention to strengthen the regulatory and supervisory frameworks, in particular given the financial sector's exposure to liquidity and credit risks stemming from large intra-group exposures and sovereign bond holdings. Directors noted the plans to strengthen the powers of the supervisory authority (CSSF). They stressed the need to increase its operational independence, as well as to clarify the roles of Central Bank of Luxembourg and the CSSF regarding liquidity risk supervision. Directors highlighted the importance of strengthening the financial safety net to facilitate restructuring of problem banks on a going-concern basis, and to revamp the deposit guarantee scheme.

Directors recognized that, given the prevalence of foreign subsidiaries in Luxembourg, a number of key financial policy areas hinge on EU-level decisions. They encouraged the authorities to remain actively involved in relevant supervisory colleges. In the absence of ex- 
ante burden-sharing arrangements for the resolution of cross border banks, Directors stressed the importance of seeking pragmatic solutions to facilitate cross border bank resolution, including through effective coordination between home and host authorities. They welcomed the authorities' swift progress in improving their AML/CFT framework.

Directors supported the authorities' decision to begin fiscal consolidation in 2011 and target a balanced budget by 2014 . They considered that consolidation should focus primarily on the expenditure side, and advised the authorities to replace the public investment cap with current spending cuts to protect growth prospects. Directors highlighted that a medium-term fiscal framework could support consolidation by facilitating expenditure review. Given the magnitude of aging-related costs, they stressed the importance of pension and health care reforms. Directors welcomed the authorities' proposal to increase the effective retirement age, and encouraged them to expeditiously implement recent health care reforms.

Directors noted that Luxembourg's growth prospects would hinge on continued efforts to promote competitiveness. In this regard, they welcomed the authorities' intention to revise the backward-looking wage indexation mechanism and revisit employment support programs to limit adverse work incentives. Continued investment in skills development will also be needed.

Public Information Notices (PINs) form part of the IMF's efforts to promote transparency of the IMF's views and analysis of economic developments and policies. With the consent of the country (or countries) concerned, PINs are issued after Executive Board discussions of Article IV consultations with member countries, of its surveillance of developments at the regional level, of post-program monitoring, and of ex post assessments of member countries with longer-term program engagements. PINs are also issued after Executive Board discussions of general policy matters, unless otherwise decided by the Executive Board in a particular case. 
Luxembourg: Selected Economic Indicators ${ }^{1 /}$

\begin{tabular}{|c|c|c|c|c|c|}
\hline & 2007 & 2008 & 2009 & 2010 & $2011^{2 /}$ \\
\hline Real economy & \multicolumn{5}{|c|}{ (Change in percent, unless otherwise indicated) } \\
\hline Real GDP & 6.6 & 1.4 & -3.6 & 3.5 & 3.2 \\
\hline Gross investment & 12.5 & 0.7 & -23.2 & 5.1 & 7.1 \\
\hline $\begin{array}{l}\text { Unemployment (as percent of the labor } \\
\text { force) }\end{array}$ & 4.4 & 4.4 & 5.8 & 6.0 & 5.9 \\
\hline Resident employment (thousands) & 207.7 & 213.7 & 215.5 & 218.1 & 222.0 \\
\hline Total employment (thousands) & 333.0 & 348.8 & 352.1 & 358.1 & 363.7 \\
\hline CPI (harmonized), p.a. & 2.7 & 4.1 & 0.0 & 2.8 & 3.7 \\
\hline Public finances & \multicolumn{5}{|c|}{ (Percent of GDP) } \\
\hline General government revenues & 39.8 & 39.8 & 41.3 & 39.5 & 36.4 \\
\hline General government expenditures & 36.2 & 36.9 & 42.2 & 41.2 & 37.3 \\
\hline General government balance & 3.7 & 3.0 & -0.9 & -1.7 & -0.9 \\
\hline General government gross debt & 6.7 & 13.6 & 14.5 & 16.5 & 17.3 \\
\hline \multicolumn{6}{|l|}{ Balance of payments } \\
\hline Current account balance & 10.1 & 5.3 & 6.9 & 7.8 & 11.5 \\
\hline Balance of trade in goods and services & 43.8 & 39.3 & 39.1 & 45.1 & 41.1 \\
\hline Factor income balance & -29.7 & -29.6 & -29.5 & -35.7 & -28.0 \\
\hline Transfer balance & -3.9 & -4.5 & -2.7 & -1.6 & -1.6 \\
\hline Exchange rates $3 /$ & \multicolumn{5}{|c|}{ Member of the euro area } \\
\hline U.S. dollar per euro & 1.4 & 1.5 & 1.4 & 1.3 & $\ldots$ \\
\hline Nominal effective rate $(2005=100)$ & 101.5 & 103.9 & 104.9 & 102.1 & $\cdots$ \\
\hline \multicolumn{6}{|c|}{ Sources: Data provided by the authorities; IMF, WEO database; and IMF staff calculations. } \\
\hline \multicolumn{6}{|c|}{$\begin{array}{l}\text { 1/ Under Article IV of the IMF's Articles of Agreement, the IMF holds bilateral discussions with } \\
\text { members, usually every year. A staff team visits the country, collects economic and financial } \\
\text { information, and discusses with officials the country's economic developments and policies. On } \\
\text { return to headquarters, the staff prepares a report, which forms the basis for discussion by the } \\
\text { Executive Board. At the conclusion of the discussion, the Managing Director, as Chairman of the } \\
\text { Board, summarizes the views of Executive Directors, and this summary is transmitted to the } \\
\text { country's authorities. }\end{array}$} \\
\hline \multicolumn{6}{|l|}{ 2/ IMF staff projections. } \\
\hline \multicolumn{6}{|l|}{ 3/ Data for 2010 refer to December. } \\
\hline
\end{tabular}




\section{Statement by Johann Prader, Alternate Executive Director for Luxembourg, and Dirk Mevis, Advisor to the Executive Director May 13, 2011}

We would like to thank staff for the fruitful and constructive dialogue during the 2011 Article IV mission and the Financial Sector Assessment Program Update (FSAP). The Luxembourg authorities broadly agree with staff's analysis.

\section{The real economy has strengthened in 2010 and the outlook is mildly positive.}

In the last quarter of 2010, the Luxembourg economy grew by 1.7 percent on a quarterly basis. For 2010 as a whole, growth reached 3.5 percent reflecting mostly a bounce back in growth from the crisis. The increases were strongest in those sectors that lost the most during the crisis e.g. manufacturing. Transportation and trade have also gained strongly. External demand from Europe and household consumption are driving the recovery. In this context, manufacturing has benefitted from partial unemployment schemes that were extended by the government in 2009 and which helped the industry to maintain the workforce and respond quickly to a resurgence of external demand. For 2011, the statistical office predicts growth just above 3 percent. Employment is picking up, with employment growth of 1.6 percent in 2010 and a slight decline in the unemployment rate in the first three months of 2011.

\section{Fiscal policy will be an important challenge going forward.}

In the context of an unexpectedly strong growth rebound in 2010, the fiscal deficit reached 1.7 percent of GDP, far lower than the expected 3.9 percent of GDP. For 2011, the authorities plan to exit from countercyclical fiscal policy and a deficit of 1.2 percent is foreseen. The budget includes a consolidation package amounting to 1.5 percent of GDP (1.1 percent expenditure, 0.4 percent revenues). It will yield savings of 1.4 percent of GDP in 2012.

Our authorities are skeptical of the staff's suggestion to let the automatic stabilizers operate fully up to the Maastricht limit. In their view the fiscal multiplier in Luxembourg is rather low. Moreover, the authorities are well aware of the political difficulty of rolling back fiscal deficits.

The medium term fiscal objectives include a balanced budget for 2014. In the medium term, a structural surplus of 0.5 percent of GDP should partially pre-fund the anticipated large ageing-related increase in public expenditures. Furthermore, the authorities intend to reform the budgetary framework. First steps of this reform will be introduced before 2014 . 


\section{Social Security systems need to be prepared for demographic ageing.}

In December 2010, parliament approved a health care reform which is intended mainly to reduce costs and improve efficiency in the Luxembourg health care system. The reform includes increases in contributions by 0.1 percentage points and the creation of a general spending envelope for hospitals. The authorities are committed to implement this reform immediately. In March 2011, the government has approved the principles of a parametric pension reform and launched a process of consultation of the social partners. The main proposed features include incentives to increase career duration. A reform of long-term care insurance is planned for 2012. The authorities are acutely aware of the challenges that demographic ageing is posing and stand ready to implement further reforms to ensure fiscal sustainability.

\section{Other structural reform needs are being considered as well.}

The automatic wage indexation remains a much debated subject in Luxembourg. A number of proposals, e.g. excluding certain components from the indexation basket or capping the level of income to be indexed, are being discussed by the social partners.

\section{The banking sector is recovering in a heterogeneous manner.}

The banking sector in Luxembourg is still adapting to a post-crisis context. While profits rose in 2010, this is almost exclusively due to lower provisioning needs. Revenues on interest rate margins declined in the current low interest rate environment. Balance sheets continue to shrink, mostly as a consequence of reductions in portfolio asset values, reductions in interbank exposures and a decrease in holdings of certain types of assets (e.g., sovereign debt).

From a more structural perspective, while some banks with certain profiles are retreating from the Luxembourg financial center - mostly as a result of restructuring measures imposed by the European Commission on rescued banking groups - large banking groups have taken decisions in favor of the Luxembourg location with its vast experience as a hub for backoffice and custodian services to the group. Private banking is also undergoing a transformation, becoming more service oriented and catering increasingly to a more sophisticated clientele. 


\section{Banks have stabilized.}

Solvency, Tier 1 capital and liquidity indicators are traditionally high in Luxembourg, although the picture varies at the micro level. Only 6 percent of banks have a solvency ratio between 8 and 10 percent in 2010 whereas on the other extreme 68 percent of banks have a solvency ratio above 15 percent. The average Tier 1 capital ratio has been 15.3 percent in 2010 and almost $85 \%$ of total own funds are core Tier 1 funds. Sovereign exposures to peripheral European countries amount to less than Euro 20 billion and have decreased continuously over the past year - including at the request of the supervisor. Stress tests performed by Fund staff and staff of the Supervisor (CSSF) during the FSAP mission confirm the relative resilience of Luxembourg banks to sovereign stress but also the absence of contagion effects in the Luxembourg banking sector from shocks affecting solvency and liquidity elsewhere.

Macro-stress tests carried out by the Banque centrale du Luxembourg (BCL) demonstrate that, despite differences at the individual bank level, Luxembourg banks are sufficiently capitalized. They show that under the severe scenario of a prolonged recession, the Luxembourg banking sector remains robust. The BCL's liquidity stress tests show that the Luxembourg financial sector remains robust not only in the face of peripheral European sovereign stress, but also to a contemporaneous interbank shock.

The local retail market has remained stable throughout the crisis. While private real estate prices have been high and increased strongly before the crisis, they have remained fairly stable - with slight declines in certain segments - since 2009. Nonetheless, the CSSF is monitoring the situation closely and has intervened to make sure the banks apply sound and prudent lending criteria.

\section{The Investment Fund industry is very dynamic and balance sheets are recovering.}

The investment fund industry has largely recovered. In March 2011 the net asset value (NAV) of the industry as a whole amounted to Euro 2.2 trillion. This is a result of both revaluation of assets held and new inflows. The number of investment funds has increased by 204 units between end 2009 and end 2010 (from 3463 to 3667). Anecdotal evidence also suggests that funds that used to be offshore before the crisis are now seeking the safety of a regulated product like the UCITS brand and redomicile in Luxembourg. Overall, it seems that the Luxembourg fund industry is exiting the crisis in a relatively unscathed manner both from a financial stability point of view and with regard to its reputation as a well regulated product. 


\section{Regulatory challenges are being addressed rapidly.}

The authorities have quickly addressed issues of concern raised by the FATF review in February 2010 and the corresponding legislation has passed parliament in November 2010. Also, some of the recommendations from the 2010 FSAP regarding the governance of the CSSF have already been addressed and the corresponding legislation has been adopted or has been introduced into the legislative process.

Draft legislation on a new deposit insurance mechanism is awaiting the finalization of discussions at the European level, before being submitted to parliament. In this context, the BCL has proposed a Financial Stability Fund combining a deposit insurance mechanism and a bank resolution fund. In March 2011, the government decided to increase the capital of the BCL, including for IMF purposes. In an effort to strengthen financial stability further, the BCL and CSSF continue recruiting highly qualified staff.

At the international level both the CSSF and the BCL are engaged in exchange, discussion and analytical work in the new European supervisory infrastructure EBA and ESRB. In addition, exchange of supervisory information and home-host coordination takes place at the level of Supervisory Colleges and Cross Border Stability Groups for all important banking groups with cross border activities. 